IZA DP No. 9840

Wellbeing Evidence for the Assessment of Progress

Paul Anand Laurence Roope Andreas Peichl

March 2016 


\title{
Wellbeing Evidence for the Assessment of Progress
}

\author{
Paul Anand \\ The Open University,

\section{Laurence Roope} \\ University of Oxford \\ Andreas Peichl \\ University of Mannheim \\ and IZA
} University of Oxford and London School of Economics
Discussion Paper No. 9840
March 2016

\author{
IZA \\ P.O. Box 7240 \\ 53072 Bonn \\ Germany \\ Phone: $+49-228-3894-0$ \\ Fax: +49-228-3894-180 \\ E-mail: iza@iza.org
}

\begin{abstract}
Any opinions expressed here are those of the author(s) and not those of IZA. Research published in this series may include views on policy, but the institute itself takes no institutional policy positions. The IZA research network is committed to the IZA Guiding Principles of Research Integrity.

The Institute for the Study of Labor (IZA) in Bonn is a local and virtual international research center and a place of communication between science, politics and business. IZA is an independent nonprofit organization supported by Deutsche Post Foundation. The center is associated with the University of Bonn and offers a stimulating research environment through its international network, workshops and conferences, data service, project support, research visits and doctoral program. IZA engages in (i) original and internationally competitive research in all fields of labor economics, (ii) development of policy concepts, and (iii) dissemination of research results and concepts to the interested public.
\end{abstract}

IZA Discussion Papers often represent preliminary work and are circulated to encourage discussion. Citation of such a paper should account for its provisional character. A revised version may be available directly from the author. 


\section{ABSTRACT}

\section{Wellbeing Evidence for the Assessment of Progress*}

In recent years considerable interest has developed in going 'beyond GDP' to develop measures of economic progress which are more explicitly based on human wellbeing. This work has been inspired, in part, by Sen's non-utilitarian approach to welfare economics, but has been constrained by a lack of empirical indicators relating to human potential. In this paper, therefore, we develop a framework for understanding wellbeing, drawing closely on Sen's seminal contributions to welfare economics, as well as the economic literature on life satisfaction, and use it to generate novel data for the USA and UK consistent with all the components of the theory. We use these data to illustrate some of the life quality analyses that might follow. Specifically, we investigate how various indicators of capability are distributed by ethnicity and gender, and compare and contrast the types of capability which appear relatively strong/weak within each country. In addition, we consider the extent to which life satisfaction and daily activities depend on resources and non-cognitive skills. The paper concludes that with an expansion of the scope of routinely collected survey data, it is feasible to empirically implement fully Sen's theory to provide a much richer account of the wellbeing outcomes that derive from economic progress than is currently the case.

JEL Classification: D60, I31

Keywords: $\quad$ wellbeing, stochastic dominance, life satisfaction, Sen

Corresponding author:

Laurence Roope

Health Economics Research Centre

Nuffield Department of Population Health

University of Oxford

New Richards Building, Old Road Campus

Oxford OX3 7LF

United Kingdom

E-mail: laurence.roope@dph.ox.ac.uk

\footnotetext{
* For comments on the paper and closely related issues, the authors particularly thank Ron Smith, Gaston Yalonetsky, Ian Crawford, Andrew Oswald, Martin Browning, Dirk Neumann, Paul Hufe, Heath Prince, Jaya Krishnakumar, Christophe Muller, Marco Mira d'Ercole, Romina Boarini, Karl Moene and Sarah Cattan, as well as participants at seminars and conferences in Austin, Harvard, Helsinki, Karlsruhe, Milan, Oxford, Paris, Sheffield and Utrecht. Our research has, in addition, benefitted significantly from discussions with colleagues in the UN Development Report Office in New York, the OECD Statistics Directorate in Paris, several departments of the World Bank and the National Wellbeing Task Force of the UK's Office for National Statistics. Last but not least, we thank James Heckman and Amartya Sen for supporting the project from which the paper derives and gratefully acknowledge its funder, the Leverhulme Trust. Usual caveats apply.
} 


\section{Introduction}

Many economists around the world are now considering how we might 'go beyond GDP' by assessing progress in terms of final human outcomes (Fleurbaey (2009), Anand et al (2011)). The current system of national income accounting, based on the major contributions of Richard Stone, Simon Kuznets and Ragnar Frisch, has a history dating back to the $17^{\text {th }}$ century work of William Petty and provides a technically sophisticated answer to questions about the value of firms' outputs. However, economists have also pointed out for some time that national income is not a measure of human wellbeing - arguably the main intended outcome of economic activity. From this perspective, income is a final output measure for firms but only an input measure for consumers and, as a result, researchers are increasingly turning to alternatives. Within economics especially, two strands of literature stand out; theories of freedom and indices of human development (Sen, 1999) on the one hand, and a large literature on the economics of happiness (see for instance Blanchflower and Oswald's (2004) wellbeing ${ }^{1}$ comparison of the US and UK) on the other. Although there is as yet no consensus on how precisely human wellbeing should be measured, ${ }^{2}$ a few guiding principles are beginning to emerge and attract some support in the field.

Firstly, and as economists from Sen (1985) through to Benjamin et al. (2014) have argued, there is growing recognition of the value of developing a multi-dimensional approach to the assessment of economic progress. To do this in a way that reflects human outcomes, an account of the space within which human wellbeing exists is needed. When it was established, the Human Development Index (HDI) added health and education to income but this is clearly only a start and leaves many high income countries rather close to each other. ${ }^{3}$ Secondly, and again as several others have indicated (e.g. Dolan and Kahneman (2008), Easterlin (1974), Helliwell (2003), and OECD (2011)), there is a need for measures that reflect subjective experience as well as the objective living conditions on which they might be based. Affluence and technological change may be associated with unintended negative consequences (for example social isolation) and so there is an issue with merely assuming that increases in income are necessarily beneficial to all. Data on

\footnotetext{
${ }^{1}$ Throughout the paper we follow the literature and make no distinction between happiness and subjective wellbeing.

${ }^{2}$ There is, however, an important and complementary line of research that shows how evaluations of progress change when the focus starts to move away from consumption and income - see especially Jones and Klenow (2011) - but also Becker et al. (2005) and Jones (2014), who notably demonstrates that optimal growth may be lower than would otherwise be the case if the value of life increases faster than the value of consumption. Another strand of the literature accounts for differences in consumption-leisure preferences - both theoretically (Fleurbaey 2008) and empirically (Bargain et al. (2013), Decoster and Haan (2015)). Both arguments can be extended to multiple dimensions of life quality and, therefore, illustrate why the kinds of measurements proposed here might be valuable even from a standard consumption perspective.

${ }^{3}$ In 2013, 16 countries had HDI scores between 0.902 and 0.881 UNDP (2013).
} 
subjective experiences may, in some cases, help to identify situations where this is not so. Thirdly, there is an interest in investigating human potential, and its development, particularly in terms of freedoms and opportunities. These 'potential' concepts have been important in economic thinking for a long time but are not always well reflected in theories about consumer behaviour, which tend to focus on optimal bundles of goods and services without reference to the decision processes by which these bundles are derived. Finally, there is growing support (e.g. Ravallion (2011)) for the view that given the diversity and nature of human wellbeing, the development of a suite of indicators is arguably more important than the creation of more summary indices. This is not to argue against such summary measures but rather to suggest that much can be learned by analysing the underlying indicators, even before any attempt at indexation.

In addition to these considerations, any approach that seeks to assess progress in terms of human wellbeing is likely to be judged in light of the achievements of national income accounting and needs to reflect similar strengths in its development. National income accounting is consistent with a theory of the determination of income, and any alternative focusing on human wellbeing outcomes should, ideally, have a counterpart theory. Moreover, national income statistics have been successful by making themselves useful so any alternative set of data should ideally sustain both the monitoring and the analysis of wellbeing.

In this paper, therefore, we offer an analysis that aims to satisfy these requirements. At a theoretical level, our approach builds directly on the three simple but core equations of Sen's (1985, pp. 11-14) approach to welfare economics. The approach was motivated by foundational problems in welfare economics theory and draws on, and reorients, simple and basic tools from neo-classical welfare economics to offer a principled, yet practical, response to some of the well-known difficulties.

Despite various initiatives and commissions (e.g. Stiglitz, Sen and Fitoussi (2009)), implementation of approaches 'going beyond GDP' has often been limited by the availability of data. Therefore, in addition to developing a theoretical framework for understanding wellbeing, we also show how a novel dataset can be constructed that corresponds to all the elements of Sen's theory. The data developed permit, in principle, many kinds of analyses. Since the approach in practice naturally gives rise to a number of ordinal measures, to compare these we also develop an approach to test for first and second order stochastic dominance that is suitable for such variables, on a dimension by dimension basis. These tests allow us to analyse inequalities in a range of domains of life beyond income covered by our data. For the purposes of this paper, we highlight three key findings. Firstly, we identify significant gender and ethnic differences, in multiple dimensions, concerning what people are able to do. Secondly, we find evidence that, out of a number of non-cognitive skills, the ability to plan ahead stands out as appearing to be related to 
both income and life satisfaction. Non-cognitive skills generally are also found to be important in converting the resources individuals are endowed with into activities that they might have reason to value. Thirdly, in comparisons between the USA and UK, we observe that their multidimensional country profiles are rather similar, with the exception of one or two notable differences which may reflect different institutional arrangements and/or preferences for economic activity by the state.

The rest of the paper is structured as follows. Section two offers a discussion of the theoretical framework and notation used, while section three provides an overview of the data developed. Section four develops the first and second order stochastic dominance techniques used to make comparisons using our ordinal measures. Empirical analyses, using stochastic dominance and regression models are presented in section five, while section six provides a concluding discussion. Descriptive statistics are given in the appendices and some supplementary materials are appended in the online version of the paper.

\section{A Framework for Measuring Wellbeing}

The framework we employ follows Sen's (1985) constructive response to the problems that emerged from the utilitarian approach to welfare economics that, in the 1960s, was implemented through advances in cost-benefit analysis. Bentham's proposal that societies should maximise the happiness of the greatest number was, at the time, an important democratic corrective but its modern normative interpretation has been taken by philosophers and economists alike as having the unintended consequence of ignoring, for example, claims based on rights (deontological claims). ${ }^{4}$ Our current theoretical approach was designed to address these philosophical problems and it decomposes human development into aspects we assign to the following three groups: the activities a person undertakes and the states that they inhabit; their experienced utility as measured by variables such as life satisfaction; and the opportunities to engage in different activities or states, given the resources and personal characteristics with which they are endowed. ${ }^{5}$ We therefore assume that there is a finite number $k \in \mathbb{N}$ of types of resources to which an individual might have access. Individual $i$ has a vector of resources given by $\mathbf{r}_{i}^{T}=\left(r_{i 1}, \ldots, r_{i k}\right) \in \mathbb{R}^{k}$. We also suppose that there is a finite number $m \in \mathbb{N}$ of types of personal traits, for example education, non-cognitive skills, personality or physical ability, which enable an individual to transform resources into

\footnotetext{
${ }^{4}$ See for instance the overview by Sen and Williams (1982) or more recent technical work by Suzumura and Xu (2009).

${ }^{5}$ Sen (1985) actually talks about 'conversion factors' and while we shall follow other economists, who have focused particularly on skills and traits (e.g. Borghans et al. (2008)), we note that, in principle, this could include other external factors that help or hinder the person convert resources into activities or states.
} 
activities and states. Individual $i$ has a vector of such characteristics given by $\boldsymbol{c}_{i}^{T}=\left(c_{i 1}, \ldots, c_{i m}\right) \in$ $\mathbb{R}^{m}$.

This notation allows that some resource and personal characteristic variables may be discrete or binary. It also permits the set of relevant resources and characteristics to differ across individuals, as they are allowed to take zero values. Through various combinations of resources and personal characteristics, individuals produce a variety of activities and states. In what follows, we just refer to activities and assume that there exists some finite number $n \in \mathbb{N}$. Individual $i$ has a vector of activities, at a point in time, given by $\boldsymbol{a}_{i}^{T}=\left(a_{i 1}, \ldots, a_{i n}\right) \in\{0,1\}^{n}$ where $a_{i j}=1$ if the individual is involved in an activity $j$ and $a_{i j}=0$ otherwise.

We think of the value of $a_{i j}$ as being determined by a production function, where resources and personal characteristics are the arguments, thus:

$$
a_{i j}=\theta_{j}\left(r_{i 1}, \ldots, r_{i k} ; c_{i 1}, \ldots, c_{i m}\right)
$$

Individual $i$ is assumed to derive utility dependent on the various activities they engage in and also, as before, some traits. This is given by:

$$
u_{i}=\lambda_{i}\left(a_{i 1}, \ldots, a_{i n} ; c_{i 1}, \ldots, c_{i m}\right) .
$$

This relation also underpins the index of wellbeing proposed by Kahneman et al. (2004), in which they develop a utilitarian assessment of wellbeing over the period of a day. So although human development and happiness research have different normative foundations and methodological approaches, they share an interest in the connection between activities and experiential aspects of wellbeing.

While activities and experiences can both provide information about wellbeing, Sen has argued to much effect that what a person can do, given their resources and skills, is also an important consideration. For this reason, we introduce a third aspect of wellbeing, namely what a person is capable of doing. Specifically, we suppose that there is a finite number $s \in \mathbb{N}$ of types of abilities to do or achieve things that an individual can have. Individual $i$ has a vector of such abilities given by $\boldsymbol{q}_{i}^{T}=\left(q_{i 1}, \ldots, q_{i s}\right) \in \mathbb{R}^{S}$, where the value of $q_{i j}$ is determined by the following production function:

$$
q_{i j}=\varphi_{j}\left(r_{i 1}, \ldots, r_{i k} ; c_{i 1}, \ldots, c_{i m}\right)
$$

The vector $\boldsymbol{q}_{i}^{T}$ describes what person $i$ is free or able to do. It therefore describes the collection of situations and states a person could be involved in, given their resources and personal 
traits. The greater the value of $q_{i j}$, the greater is individual $i$ 's degree of freedom or capability in dimension $j$. Equation (3) describes the relationship between capabilities and resources and traits. By combining (1) and (2), it follows immediately that utility, our experiential component of wellbeing, can be expressed as follows:

$$
u_{i}=\rho_{i}\left(r_{i 1}, \ldots, r_{i k} ; c_{i 1}, \ldots, c_{i m}\right)
$$

We interpret equations (3) and (4) as production functions, analogous to those for firms, where the outputs are aspects of human wellbeing. ${ }^{6}$ Finally, since the variables in (3) which produce $q_{i j}$ are the same for all $j$, any simple summary index of individual $i$ 's capability based on $\boldsymbol{q}_{i}^{T}$, can be expressed in a similar manner to (3), as a function of resources and traits.

Human wellbeing, then, has different elements and in what follows we focus particularly on multiple dimensions of individual capabilities and experience, and on their associations with resources and skills. In our empirical analyses, as a key element of our framework, we create summary capability indices corresponding to individual $i$ 's capabilities with respect to Home, Work, Community, Environment and Access to Services. These indices are denoted as $Q_{i H}$, $Q_{i W}, Q_{i C}, Q_{i E}$ and $Q_{i S}$ and each can be expressed in a similar form to (3).

They are obtained using a threshold plus counting method, similar to that which has become popular in the literature on multi-dimensional poverty (e.g. Alkire and Foster (2011)) and affluence (e.g. Peichl and Pestel (2013)) measurement. ${ }^{7}$ To measure individual home-related capabilities, we have seven sub-domain indicators, each of which takes a response on an 11-point scale from ' 0 ' to '10' ranging from 'disagree' to 'strongly agree.' Typically, responses can be conveniently divided into groupings from 0-5 and from 6-10 and expressed as binary indicators $q_{i j} \in\{0,1\}$, where $i$ denotes the individual and $j \in\{1, \cdots, 7\}$ denotes the $j$-th sub-domain. A summary index for this and other domains, for the $i$-th individual, $Q_{i H}$, is then created by summing over the seven sub-domains, i.e. $Q_{i H}=\sum_{j=1}^{7} q_{i j}$. In principle, these aspects of life quality could be considered to give rise to a total lifetime capability expressed as $\int_{t=0}^{T}\left(\sum_{l=1}^{5} \alpha_{l} Q_{i l t}\right) d t$, where $l \in\{H, W, C, E, S\}, \alpha_{l} \in \mathbb{R}_{+}$is the

\footnotetext{
${ }^{6}$ Note that while in (3) we impose the same functional form $\varphi_{j}$ for all individuals, in (4) we allow for the possibility that different individuals may have different utility production functions. However, in order to analyse the production of utility econometrically, we will later make the simplifying assumption that $\rho_{i}=\rho$ for all individuals.

${ }^{7}$ Our approach is also consistent with Nehring and Puppe (2002)'s axiomatic work on measuring the diversity of a set by summing the values of attributes possessed by members of the set. It is also worth mentioning that comparisons of multi-dimensional opportunity sets have been axiomatised by Klemisch-Alhert (1993).
} 
weight attached to domain $l$, and $t$ denotes age, from birth $(t=0)$ through to death $(t=T) .{ }^{8}$ In the empirical work that follows, however, we have to focus on life quality as assessed by the five separate capability domains at a single point in time due to the cross-sectional nature of the data developed in the next section, that are consistent with each of the theoretical elements.

\section{Data}

The data generated were designed to implement the theoretical framework discussed above. A widely accepted view that capability measurement is either difficult in principle or rare in practice, ${ }^{9}$ has given way in recent years to a more pragmatic concern that there are simply few existing datasets with variables that closely correspond to all the elements of Sen's theory. We therefore focus on the construction of a survey instrument which can be used to develop such data. Our surveys are developed for the USA and the UK, to illustrate application of our approach to monitoring wellbeing at a national level. The questions are designed to provide data relating to what people are able to do, their experiences, activity involvement, resources and skills, as well as a range of standard socio-demographic variables.

In the empirical analyses that follow in Section 5, we make use of data concerning what people are able to do across 29 different dimensions, together with data on activity involvement and measures of experience such as life satisfaction, which is now widely used in empirical work. Some descriptive statistics are presented in Table 1(a) and 1(b). Question wording draws on previous work (see for example Anand et al. (2009)), which in turn was informed by the design of a number of national household surveys, particularly the British Household Panel Survey, the German Socio-Economic Panel survey and the Panel Survey of Income Dynamics. The dimensions of capability covered owe much to objective list accounts of human flourishing, particularly a widely discussed list from the political philosophy literature, produced by Nussbaum (2000). Our dimensions also draw on a survey of dimensions proposed by some forty such lists ${ }^{10}$, a consultation exercise conducted by the ONS (2012) with over 30,000 members of the UK general public, and the OECD (2011) Better Life Compendium, based on available national data for member states. Our measures of experience include four questions about life satisfaction, happiness yesterday and anxiety yesterday. Different measures of experience respond differently to external changes and, as a result, there is growing interest in a variety of experience indicators beyond questions about

\footnotetext{
${ }^{8}$ For a discussion of the weighting process in summary multidimensional wellbeing indices, see Decancq and Lugo (2013).

${ }^{9}$ See for instance Brandolini and D'Alessio (1998). The main alternative to our approach is to explore the use of latent variable techniques - see for instance Schokkaert and van Ootegem (1989).

${ }^{10}$ See, inter alia, Anand et al. (2011).
} 
Table 1a: Individual Capabilities \& Life Satisfaction

\begin{tabular}{|c|c|c|c|c|}
\hline \multirow[b]{2}{*}{ Home ("Thinking about your home life...") } & \multicolumn{2}{|c|}{ USA } & \multicolumn{2}{|c|}{ UK } \\
\hline & Mean & S.D & Mean & S.D \\
\hline I am able to share domestic tasks within the household fairly & 6.64 & 2.90 & 6.11 & 3.12 \\
\hline I am able to socialise with others in the family as I would wish & 6.96 & 2.67 & 6.40 & 2.72 \\
\hline I am able to make ends meet & 6.36 & 2.93 & 6.28 & 2.76 \\
\hline I am able to achieve a good work-life balance & 5.98 & 2.95 & 5.81 & 2.87 \\
\hline I am able to find a home suitable for my needs & 6.96 & 2.76 & 6.52 & 2.71 \\
\hline I am able to enjoy the kinds of personal relationships that I want & 6.40 & 2.92 & 6.16 & 2.90 \\
\hline I have good opportunities to feel valued and loved & 6.92 & 2.73 & 6.26 & 2.77 \\
\hline \multicolumn{5}{|l|}{ Work ("Thinking about work...") } \\
\hline I am able to find work when I need to & 6.97 & 2.70 & 6.50 & 2.75 \\
\hline I am able to use my talents and skills at work & 7.07 & 2.60 & 6.51 & 2.57 \\
\hline I am able to work under a good manager at the moment & 6.79 & 2.96 & 6.10 & 2.84 \\
\hline $\begin{array}{l}\text { I am always treated as an equal (and not discriminated against) by } \\
\text { people at work }\end{array}$ & 7.39 & 2.69 & 6.78 & 2.70 \\
\hline I have good opportunities for promotion or recognition at work & 5.90 & 3.03 & 4.77 & 3.00 \\
\hline I have good opportunities to socialise at work & 6.72 & 2.76 & 5.58 & 2.72 \\
\hline \multicolumn{5}{|l|}{ Community (“Thinking about your community...”) } \\
\hline I have good opportunities to take part in local social events & 5.94 & 2.86 & 4.95 & 2.73 \\
\hline $\begin{array}{l}\text { I am treated by people where I live as an equal (and not } \\
\text { discriminated against) }\end{array}$ & 7.60 & 2.46 & 7.09 & 2.47 \\
\hline $\begin{array}{l}\text { I am able to practice my religious beliefs (including } \\
\text { atheism/agnosticism) }\end{array}$ & 8.12 & 2.42 & 7.59 & 2.47 \\
\hline I am able to express my political views when I wish & 7.56 & 2.48 & 7.23 & 2.40 \\
\hline \multicolumn{5}{|l|}{ Environment (“Thinking about your local environment...”) } \\
\hline I am able to walk in my local neighbourhood safely at night & 7.47 & 2.64 & 6.78 & 2.58 \\
\hline I am able visit parks or countryside whenever I want & 7.55 & 2.66 & 7.42 & 2.56 \\
\hline $\begin{array}{l}\text { I am able to work in an environment that has little pollution from } \\
\text { cars or other }\end{array}$ & 6.36 & 2.95 & 5.87 & 2.87 \\
\hline I am able to keep a pet or animals at home with ease if I so wish & 7.77 & 2.97 & 7.11 & 3.18 \\
\hline I am able to get to places I need to without difficulty & 7.56 & 2.66 & 6.97 & 2.74 \\
\hline \multicolumn{5}{|l|}{ Access to services (When needed, I find it easy to...”) } \\
\hline I find it easy to make use of banking and personal finance services & 7.92 & 2.33 & 7.62 & 2.26 \\
\hline I find it easy to get my rubbish cleared away & 8.25 & 2.18 & 7.45 & 2.29 \\
\hline $\begin{array}{l}\text { I find it easy to get trades people or the landlord to help fix } \\
\text { problems in the house }\end{array}$ & 7.15 & 2.76 & 6.69 & 2.54 \\
\hline I find it easy to be treated by a doctor or nurse & 7.52 & 2.69 & 7.27 & 2.35 \\
\hline I find it easy to get help from the police & 7.67 & 2.45 & 6.81 & 2.50 \\
\hline I find it easy to get help from a solicitor & 6.36 & 2.95 & 6.78 & 2.52 \\
\hline I find it easy to get to a range of shops & 7.76 & 2.42 & 7.60 & 2.33 \\
\hline "Overall how satisfied are you with your life nowadays" & 6.32 & 2.30 & 5.90 & 2.31 \\
\hline
\end{tabular}

Notes: (i) In USA, $\mathrm{N}=723$ for Work domain response items; $\mathrm{N}=1,059$ for all other domains. In UK, $\mathrm{N}=1,243$ for Work domain response items; $\mathrm{N}=1,616$ for "...find it easy to get to a range of shops;" $\mathrm{N}=1,689$ for all other response items (ii) Capability questions preceded by text "Here are some questions about the opportunities and constraints that you face. For each of the following statements, please indicate how much you agree, or disagree on a scale of 0 to 10 , where 0 indicates you strongly disagree and 10 that you strongly agree." 
Table 1b: Activity involvement yesterday

\begin{tabular}{|c|c|c|c|c|}
\hline \multirow[b]{3}{*}{ Activities } & \multicolumn{2}{|c|}{$\overline{U S A}$} & \multicolumn{2}{|c|}{$U K$} \\
\hline & $\begin{array}{l}\text { Yesterday was } \\
\text { a normal } \\
\text { working day }\end{array}$ & $\begin{array}{c}\text { Yesterday } \\
\text { was not a } \\
\text { normal } \\
\text { working day }\end{array}$ & $\begin{array}{c}\text { Yesterday } \\
\text { was a } \\
\text { normal } \\
\text { working } \\
\text { day }\end{array}$ & $\begin{array}{c}\text { Yesterday } \\
\text { was not a } \\
\text { normal } \\
\text { working } \\
\text { day }\end{array}$ \\
\hline & \multicolumn{4}{|c|}{$\%$ of respondents } \\
\hline Attending an evening class & 4.9 & 3.9 & 1.9 & 2.8 \\
\hline Caring for someone ill (unpaid) & 5.6 & 8.9 & 7.7 & 7.2 \\
\hline Commuting & 37.6 & 23.9 & 31.4 & 20.2 \\
\hline Cooking & 47.6 & 47.8 & 48.7 & 43.6 \\
\hline DIY & 11.8 & 13.1 & 9.9 & 10.8 \\
\hline Drinking Alcohol & 22.6 & 28.3 & 26.8 & 28.5 \\
\hline Exercising & 33.3 & 28.1 & 24.9 & 21.7 \\
\hline Housework & 55.3 & 54.3 & 49.1 & 43.4 \\
\hline Internet (for personal use) & 80.1 & 76.6 & 78.9 & 74.9 \\
\hline Internet (for paid employment) & 30.1 & 15.2 & 25 & 13.4 \\
\hline Intimate relations & 20.2 & 27.8 & 12.8 & 16.4 \\
\hline Listening to music & 60.6 & 56.7 & 48 & 44.3 \\
\hline Looking after a pet & 45.9 & 40.4 & 33.7 & 29.6 \\
\hline Other outdoor activities & 17.3 & 17.3 & 8.1 & 13.2 \\
\hline Paid employment & 52.4 & 24.4 & 58.5 & 26.4 \\
\hline Playing a musical instrument & 6.9 & 5.8 & 6.4 & 5.1 \\
\hline Praying or meditating & 31.9 & 24.7 & 6.4 & 6.6 \\
\hline Relaxing or napping & 41.3 & 44.4 & 30.4 & 32.5 \\
\hline Reading for pleasure & 45.9 & 45.1 & 47.8 & 44 \\
\hline Self-care & 41.0 & 38.1 & 24.3 & 21.9 \\
\hline Smoking tobacco & 17.8 & 15.2 & 14.4 & 10.6 \\
\hline Socialising & 39.5 & 41.7 & 24.1 & 30.2 \\
\hline Shopping & 30.4 & 35.2 & 34.3 & 32.6 \\
\hline Time with children & 32.7 & 29.7 & 28.8 & 24.5 \\
\hline Visiting a park or the countryside & 11.2 & 13.6 & 11 & 14.9 \\
\hline $\begin{array}{l}\text { Visiting a } \\
\text { cinema/concert/gallery/museum }\end{array}$ & 11.5 & 14.7 & 9.3 & 8.1 \\
\hline Volunteering & 12.1 & 9.4 & 6.2 & 4.9 \\
\hline Watching TV & 76.0 & 70.6 & 76.6 & 70.6 \\
\hline Other & 3.2 & 6.6 & 2.2 & 6.6 \\
\hline
\end{tabular}

Note: (i) In USA: $\mathrm{N}=678$ for those reporting yesterday was a normal working day; $\mathrm{N}=381$ for those reporting yesterday was not a normal working day. (ii) In UK: $\mathrm{N}=1,086$ for those reporting yesterday was a normal working day; $\mathrm{N}=530$ for those reporting yesterday was not a normal working day. 
life satisfaction or happiness. ${ }^{11}$ Measures of activity used here are a slight modification of an account developed by White and Dolan (2009), which was in turn based on initial work by Kahneman et al. (2004). For present purposes, we use a question based on activity involvement yesterday and record whether yesterday was a normal working day or not. This formulation is, in effect, a short-form version of questions that often appear in time-use research and enables us to ask about activities that might plausibly be remembered with reasonable accuracy without resorting to diary keeping. ${ }^{12}$

Finally, recognising that personal traits such as non-cognitive skills are allowed for in this framework, and are of increasing interest to economists (e.g. Cunha and Heckman (2008), Cunha et al. (2010), Heckman et al. (2013)), we asked several questions about a range of potentially relevant characteristics in addition to the standard 'big five' personality traits. In his original account, Sen (1985) discusses what he calls 'conversion factors' that help individuals convert resources into activities and states. In principle, these might include factors such as social norms, which apply to particular types of people and might not be classified as non-cognitive skills. Here, we consider skills to do with what might loosely be regarded as 'task completion' or 'social performance.'

In 2011, we held a workshop with disciplinary experts from economics, psychology, philosophy and a national statistics office, to finalise a design that was subsequently piloted and delivered by a political polling and market research company. The full survey was conducted in early 2012 with samples from the company's online panels, selected to be roughly representative of working age adults. A selection of descriptive statistics is presented in Appendix A. ${ }^{13}$

There is considerable interest in the development of dashboards of data for monitoring the human impacts of economic activity and in what follows we illustrate some of the analyses that might be supported by such data. Before coming to that analysis, however, in the section that follows we develop the stochastic dominance tests that are suitable for comparing groups, given that much of our data are ordinal in nature.

\footnotetext{
${ }^{11}$ See, for example, Clark and Senik (2011).

${ }^{12}$ While not a primary aim, we were concerned with creating a short form survey that might plausibly be incorporated into other surveys, a common approach in psychometric and health research.

${ }^{13}$ The workshop was held at Brasenose College in Oxford and the data were collected by YOUGOV. In addition to the US and UK samples, an Italian sample was collected. However, the composition of the Italian sample appears slightly different to that of the USA and UK. For one thing, higher education participation rates in the Italian sample are significantly lower than in those for the US and UK and, for these reasons, the main part of the paper focuses on the US and UK results while some additional results for Italy are given in the supplementary materials.
} 


\section{Stochastic dominance with ordinal variables}

Our analysis of empirical results begins with a comparison of within country inequalities, as indicated by differences in the distributions of individual capabilities among different groups. Standard stochastic dominance techniques cannot be applied given the ordinal nature of the data, as the dominance conditions and associated statistical tests are based on a continuity assumption, which does not apply here. However, Yalonetsky (2013) recently developed stochastic dominance results, and associated statistical tests, for multi-dimensional data measured on ordinal scales. However, even in quite large samples and with just a few dimensions, it can be difficult to obtain statistically significant results between groups. ${ }^{14}$ Moreover, dominance in a particular given dimension may often be of interest in its own right, regardless of its joint distribution with other dimensions. As a result, we offer an approach to dominance that is suitable for use with ordinal data on a dimension by dimension basis.

Suppose that there are $N_{g}$ individuals in group $g \in\{A, B\}$. Each individual has an attainment in some common wellbeing domain which lies in one of $S \in \mathbb{N}$ ordinal categories. Let $\boldsymbol{\omega}_{g} \in \mathbb{N}_{\uparrow}^{N_{g}}$ for $g \in\{A, B\}$ be a vector of wellbeing scores, where the subscript $\uparrow$ indicates that wellbeing attainments are weakly ordered from lowest to highest. The $i$ th element of $\boldsymbol{\omega}_{g}$ is given by $\omega_{i g} \in\{1, \cdots, S\}$. Following Yalonetzky (2013), we focus on the class of social wellbeing functions that are additively separable and symmetric with respect to individuals. ${ }^{15}$ The class of all such social wellbeing functions $\Omega$, unique up to positive affine transformations, can be defined as

$$
\Omega=\left\{W\left(\boldsymbol{\omega}_{g}\right): W\left(\boldsymbol{\omega}_{g}\right)=\sum_{i=1}^{N_{g}} \alpha_{i} u\left(\omega_{i g}\right)\right\},
$$

where $\alpha_{i} \geq 0$ for all $i \in\left\{1, \cdots, N_{g}\right\}, \sum_{i=1}^{N_{g}} \alpha_{i}=1$ and the function $u: \mathbb{N} \rightarrow \mathbb{R}$ can be interpreted either as an individual-level wellbeing evaluation function (of which a utility function is a special case) or simply as a cardinal scale.

\footnotetext{
14 This is related to the 'curse of dimensionality' that arises when rapidly increasing demands are placed on data when the number of dimensions increases. Intuitively similar points in K-dimensional space become further apart as $\mathrm{K}$ increases, density surfaces become flatter, and it becomes harder to distinguish between distributions. In ongoing work, Anderson et al. (2014) develop an approach to creating multi-dimensional deprivation indices that deal with this issue. These limitations are at least suggested in some of the earlier works in this area - see for example Atkinson and Bourguignon (1982).

${ }^{15}$ We use the term 'social wellbeing function' rather than 'social welfare function' simply to emphasise that the function's arguments are variables not typically used in welfare economics. The simplifying assumption of additive separability, though quite restrictive, is widely made and such social welfare functions are well known to have a number of attractive properties, most obviously subgroup consistency.
} 
For $k \in\{1, \cdots, S\}$, let us denote the cumulative probability function by $F_{g}(k) \equiv \operatorname{Pr}\left(\omega_{i g} \leq\right.$ $k)$. In what follows it will also be convenient to define the differences in wellbeing and cumulative probability functions, respectively, between the two groups as

$\Delta W \equiv W\left(\boldsymbol{\omega}_{A}\right)-W\left(\boldsymbol{\omega}_{B}\right)$ and $\Delta F(\cdot) \equiv F_{A}(\cdot)-F_{B}(\cdot)$.

We can now write the following stochastic dominance conditions:

(D1) First Order Stochastic Dominance (FOSD):

$\Delta W \geq 0 \Leftrightarrow \Delta F(k) \leq 0 \forall k \in\{1, \cdots, S-1\}$ and all $u(\cdot) \in U^{1}$, where the class $U^{1}$ is defined as:

$U^{1}=\{u(\cdot): u(k+1)-u(k) \geq 0 \forall k \in\{1, \cdots, S-1\}\}$.

The only restriction then on the function $u(\cdot)$ is a very mild one of weak monotonicity; ordinal categories are assigned weakly higher cardinal values according to their relative desirability. If group A is found to have FOSD over group B then we can conclude that A is ranked as being preferable to $\mathrm{B}$, with respect to social wellbeing based on our wellbeing domain, by any such function $u(\cdot) \in U^{1}$.

(D2) Second Order Stochastic Dominance (SOSD):

$\Delta W \geq 0 \Leftrightarrow \Delta H(k) \equiv \sum_{j=1}^{k} \Delta F(j) \leq 0 \forall k \in\{1, \cdots, S-1\}$ and all $u(\cdot) \in U^{2}$, where the class $U^{2}$ is defined as:

$U^{2}=\left\{u(\cdot): u(\cdot) \in U^{1}\right.$ and $[(u(k+2)-u(k+1))-(u(k+1)-u(k))] \leq 0 \forall k \in$ $\{1, \cdots, S-2\}\}$.

Here the form of the function $u(\cdot)$ is further constrained by imposing a concavity restriction. As with cardinal data, clearly FOSD implies SOSD and is the first condition to check. If FOSD does not hold, the two groups may still be ranked for a broad class of social wellbeing functions if SOSD holds.

Yalonetzky (2013) also provides an ordinal variable extension of Anderson (1996)'s nonparametric statistical tests for stochastic dominance in empirical applications. The univariate versions of these tests for FOSD and SOSD in the present setting are as follows. ${ }^{16}$ Let $p_{k g}$ be the

\footnotetext{
${ }^{16}$ Yalonetzky (2013) provides only multivariate results, for two or more variables. The univariate results provided here are very closely related and more easily derived.
} 
probability that a randomly selected individual from group $g \in\{A, B\}$ has a capability attainment in category $k \in\{1, \cdots S\}$ and let $\boldsymbol{p}_{g} \in[0,1]^{S}$ be the corresponding vector of probabilities. The empirical estimate of $p_{k g}$ from a random sample of $n_{g} \leq N_{g}$ is given by

$$
\hat{p}_{k g}=\frac{1}{n_{g}} \sum_{i=1}^{n_{g}} I\left(k_{i}\right) \text {, }
$$

where $\left(k_{i}\right) \equiv\left\{\begin{array}{c}1 \text { if } k_{i}=k \\ 0 \text { otherwise }\end{array}\right.$.

Let $\widehat{\boldsymbol{p}}_{g}$ be the corresponding vector of empirical estimates and let $\mathbf{0}$ denote an $S$-vector of zeros. Using results by Formby, Smith and Zheng (2004), we can then write the asymptotic result:

$$
\sqrt{n_{g}}\left(\widehat{\boldsymbol{p}}_{g}-\boldsymbol{p}_{g}\right) \stackrel{d}{\rightarrow} N\left(\mathbf{0}, \boldsymbol{\Omega}_{g}\right)
$$

where the $S$-dimensional covariance matrix $\boldsymbol{\Omega}_{g}$ is such that its $(k, l)$ th element is equal to $p_{k g}\left(1-p_{k g}\right)$ whenever $k=l$ and $-p_{k g} p_{l g}$ otherwise. Now denote $\boldsymbol{v}=\left(\widehat{\boldsymbol{p}}_{A-} \widehat{\boldsymbol{p}}_{B}\right)$. Under the null hypothesis that groups A and B are identically distributed,

$$
\boldsymbol{v} \stackrel{d}{\rightarrow} N\left(\mathbf{0}, \frac{n_{A}+n_{B}}{n_{A} n_{B}} \mathbf{\Omega}\right)
$$

where $\boldsymbol{\Omega}=\boldsymbol{\Omega}_{g}$ for any $g \in\{A, B\}$.

Some further notation is helpful at this point. Let $\Delta \mathbf{F}$ and $\Delta \mathbf{H}$ denote the $S$-vectors with $k$ th elements $\Delta F(k)$ and $\Delta H(k)$, respectively, and let the corresponding test statistic vectors be denoted by $\widehat{\Delta \mathbf{F}}$ and $\widehat{\Delta \mathbf{H}}$. Let $\widehat{\mathbf{\Omega}}_{g}$ be the estimate of the covariance matrix $\boldsymbol{\Omega}_{g}$, with $(k, l)$ th element equal to $\hat{p}_{k g}\left(1-\hat{p}_{k g}\right)$ whenever $k=l$ and $-\hat{p}_{k g} \hat{p}_{l g}$ otherwise. We also define $\mathbf{L}$ as an $S$-dimensional lower triangular matrix of ones.

We can now write the statistical tests for FOSD and SOSD.

(S1) The $k$ th element of the test statistic for $\Delta \mathbf{F}$ is given by

$$
\widehat{\Delta F}(k)=\sum_{j=1}^{k} v_{j}=\sum_{j=1}^{k}\left(\hat{p}_{j A}-\hat{p}_{j B}\right) \text {. }
$$

Now, under the assumption that the samples from A and B are independent,

$$
\operatorname{var}(\widehat{\Delta \mathbf{F}})=\mathbf{L}\left(\frac{\mathbf{1}}{n_{A}} \widehat{\boldsymbol{\Omega}}_{A}+\frac{\mathbf{1}}{n_{B}} \widehat{\boldsymbol{\Omega}}_{B}\right) \mathbf{L}^{\prime} .
$$


For each $k \in\{1, \cdots, S\}$, the corresponding z-statistic $Z_{k}^{I}$ is obtained by dividing $\widehat{\Delta F}(k)$ by its standard error (S.E), which is given by the square root of the $k$ th diagonal element of $\operatorname{var}(\widehat{\Delta \mathbf{F}})$. Thus,

$$
Z_{k}^{I}=\frac{\sum_{j=1}^{k}\left(\hat{p}_{j A}-\hat{p}_{j B}\right)}{S \cdot E \cdot(\widehat{\Delta F}(k))}
$$

where $S . E .(\widehat{\Delta F}(k))=\sqrt{\sum_{j=1}^{k}\left(\frac{\hat{p}_{j A}}{n_{A}}\left(1-\hat{p}_{j A}-2 \sum_{l=j+1}^{k} \hat{p}_{l A}\right)+\frac{\hat{p}_{j B}}{n_{B}}\left(1-\hat{p}_{j B}-2 \sum_{l=j+1}^{k} \hat{p}_{l B}\right)\right)}$.

We now consider the null hypothesis that A does not FOSD B.

$H_{0}: \Delta F(k)>0$ for some $k \in\{1, \cdots, S-1\}$.

$H_{1}: \Delta F(k) \leq 0$ for all $k \in\{1, \cdots, S-1\}$.

$H_{0}$ is rejected if and only if $Z_{k}^{I} \leq-Z^{*}<0$ for all $k \in\{1, \cdots, S-1\}$, where $-Z^{*}$ is the left-tail critical value for a desired level of statistical significance. ${ }^{17}$

(S2) The $k$ th element of the test statistic for $\Delta \mathbf{H}$ is given by $\widehat{\Delta H}(k)=\sum_{j=1}^{k} \widehat{\Delta F}(j)$.

Similarly to above, under the assumption that the samples from A and B are independent,

$$
\operatorname{var}(\widehat{\Delta \mathbf{H}})=\mathbf{L}^{2}\left(\frac{1}{n_{A}} \widehat{\boldsymbol{\Omega}}_{A}+\frac{1}{n_{B}} \widehat{\boldsymbol{\Omega}}_{B}\right) \mathbf{L}^{\prime 2}
$$

For each $k \in\{1, \cdots, S-1\}$, the corresponding z-statistic $Z_{k}^{I I}$ is obtained by dividing $\widehat{\Delta H}(k)$ by its standard error, which is given by the square root of the $k$ th diagonal element of $\operatorname{var}(\widehat{\Delta \mathbf{H}})$. Thus,

$$
Z_{k}^{I I}=\frac{\sum_{j=1}^{k} \widehat{\Delta F}(j)}{S . E \cdot(\widehat{\Delta H}(k))}
$$

where $S . E \cdot(\widehat{\Delta H}(k))=\sqrt{\sum_{g \in G} \frac{1}{n_{g}}\left(\begin{array}{c}\sum_{j=1}^{k}(k-j+1)^{2} \hat{p}_{j g}\left(1-\hat{p}_{j g}\right)- \\ 2 \sum_{j=1}^{k-1}(k-j+1) \hat{p}_{j g} \sum_{l=j+1}^{k}(k-l+1) \hat{p}_{l g}\end{array}\right)}$.

${ }^{17}$ Other rejection rules are possible; this rather strict rejection rule is from Howes (1996). 
We now consider the null hypothesis that A does not SOSD B. The test is similar to the firstorder test.

$H_{0}: \Delta H(k)>0$ for some $k \in\{1, \cdots, S-1\}$.

$H_{1}: \Delta H(k) \leq 0$ for all $k \in\{1, \cdots, S-1\}$.

$H_{0}$ is rejected if and only if $Z_{k}^{I I} \leq-Z^{*}<0$ for all $k \in\{1, \cdots, S-1\}$, where $-Z^{*}$ is the left-tail critical value for a desired level of statistical significance. In the following section, we use these results to make within country comparisons of wellbeing by ethnicity and gender.

\section{Empirical Findings}

To begin, we use the FOSD and SOSD tests derived above to make some intra-country comparisons on multiple dimensions of wellbeing. In principle, many such comparisons are possible with this dataset. For tractability, we restrict our focus in this section to capabilities in the home, at work and in the physical environment. In the USA sample, comparing whites with non-whites, the former are found to dominate non-whites at second order, at least, in all domains analysed (see Table 2(a)), and to FOSD non-whites in the physical environment domain, at the $1 \%$ significance level. The results also suggest that whites in the UK have higher levels of wellbeing than non-whites across each domain though the results are not statistically significant. The proportion of non-whites in the UK is considerably smaller than in the US and may contribute to lack of statistical significance. Nonetheless, taken together, the results suggest that ethnic disparities are found in a number of important areas of life in both countries.

Comparing men and women in the USA (see Table 2(b)), the former FOSD the latter in all three domains, though the results are only (marginally) statistically significant in the Environment domain. Males SOSD females in the home domain at the 5\% significance level. Overall, the results indicate significant gender disparities, favouring males, in a number of domains in the USA. Analysis of gender disparities in the UK provides inconclusive results. ${ }^{18}$

Taken together, these findings suggest that well-known ethnic and gender inequalities found in income are evident also in a variety of other domains. They are more evident in the USA than in the UK, and inequalities related to the physical environment are perhaps the most clear-cut. Understandably, there is considerable interest in the growth of income inequality, but this evidence suggests that inequalities with respect to local environment may also be a cause for concern.

\footnotetext{
${ }^{18}$ However, in unreported results for income, males FOSD females in our sample at the $10 \%$ level, and SOSD females at the $5 \%$ level.
} 
Table 2(a) First and Second Order Dominance Test Results: Whites compared with Non-Whites

\begin{tabular}{ccccccccccccc}
\hline \hline & \multicolumn{2}{c}{ USA Home } & \multicolumn{2}{c}{ UK Home } & \multicolumn{2}{c}{ USA Work } & \multicolumn{2}{c}{ UK Work } & \multicolumn{2}{c}{ USA Environment } & \multicolumn{2}{c}{ UK Environment } \\
\hline$k$ & $\widehat{\Delta F}(k)$ & $\widehat{\Delta H}(k)$ & $\widehat{\Delta F}(k)$ & $\widehat{\Delta H}(k)$ & $\widehat{\Delta F}(k)$ & $\widehat{\Delta H}(k)$ & $\widehat{\Delta F}(k)$ & $\widehat{\Delta H}(k)$ & $\widehat{\Delta F}(k)$ & $\widehat{\Delta H}(k)$ & $\widehat{\Delta F}(k)$ & $\widehat{\Delta H}(k)$ \\
\hline 0 & -0.0761 & -0.0761 & -0.0068 & -0.0068 & -0.0554 & -0.0554 & -0.053 & -0.053 & -0.0681 & -0.0681 & -0.0437 & -0.0437 \\
1 & -0.0833 & -0.1594 & -0.0811 & -0.0879 & -0.0524 & -0.1078 & -0.0582 & -0.1112 & -0.0945 & -0.1626 & -0.08 & -0.1237 \\
2 & -0.0532 & -0.2126 & -0.0486 & -0.1365 & -0.0101 & -0.1179 & -0.0975 & -0.2087 & -0.1145 & -0.2771 & -0.1143 & -0.238 \\
3 & -0.0289 & -0.2415 & -0.0748 & -0.2113 & 0.0013 & -0.1166 & -0.1701 & -0.3788 & -0.0978 & -0.3749 & -0.1361 & -0.3741 \\
4 & 0.0004 & -0.2411 & -0.0973 & -0.3086 & 0.0575 & -0.0591 & -0.1082 & -0.487 & -0.1185 & -0.4934 & -0.1923 & -0.5664 \\
5 & 0.0394 & -0.2017 & -0.1216 & -0.4302 & 0.0485 & -0.0106 & -0.0438 & -0.5308 & & \\
6 & 0.031 & -0.1707 & -0.0365 & -0.4667 & & & & & & \\
7 & & & & & & & & & & \\
\hline Test & NR & Whites & Whites & Whites & NR & Whites & Whites & Whites & Whites & Whites & Whites & Whites \\
Result & & SOSD & FOSD & SOSD & & SOSD & FOSD & SOSD & FOSD $* * *$ & SOSD*** & FOSD & SOSD \\
\hline
\end{tabular}

1. US: $\mathrm{N}=845$ for whites \& 214 for non-whites for Home and Environment; $\mathrm{N}=586$ for whites \& 137 for non-whites for Work. UK: N=1,599 for whites \& 64 for non-whites for Home and Environment; N=1,177 for whites \& 47 for non-whites for Work.

2. Here, and throughout the paper, $* * *$ and $* * *$ indicate statistical significance at $10 \%, 5 \%$ and $1 \%$ levels, respectively.

3. $\mathrm{NR}=$ inconclusive result, here and in Table 1(b).

Table 2(b) First and Second Order Dominance Test Results: Males compared with Females

\begin{tabular}{|c|c|c|c|c|c|c|c|c|c|c|c|c|}
\hline \multirow[b]{2}{*}{$k$} & \multicolumn{2}{|c|}{ USA Home } & \multicolumn{2}{|c|}{ UK Home } & \multicolumn{2}{|c|}{ USA Work } & \multicolumn{2}{|c|}{ UK Work } & \multicolumn{2}{|c|}{ USA Environment } & \multicolumn{2}{|c|}{ UK Environment } \\
\hline & $\widehat{\Delta F}(k)$ & $\widehat{\Delta H}(k)$ & $\widehat{\Delta F}(k)$ & $\widehat{\Delta H}(k)$ & $\widehat{\Delta F}(k)$ & $\widehat{\Delta H}(k)$ & $\widehat{\Delta F}(k)$ & $\widehat{\Delta H}(k)$ & $\widehat{\Delta F}(k)$ & $\widehat{\Delta H}(k)$ & $\widehat{\Delta F}(k)$ & $\widehat{\Delta H}(k)$ \\
\hline 0 & -0.036 & -0.036 & 0.0066 & 0.0066 & -0.0163 & -0.0163 & 0.0029 & 0.0029 & -0.0284 & -0.0284 & 0.008 & 0.008 \\
\hline 1 & -0.0437 & -0.0797 & -0.0067 & -0.0001 & -0.0413 & -0.0576 & -0.0061 & -0.0032 & -0.0511 & -0.0795 & -0.0064 & 0.0016 \\
\hline 2 & -0.0439 & -0.1236 & -0.001 & -0.0011 & -0.0428 & -0.1004 & -0.0008 & -0.004 & -0.0682 & -0.1477 & 0.0003 & 0.0019 \\
\hline 3 & -0.0459 & -0.1695 & -0.0048 & -0.0059 & -0.048 & -0.1484 & 0.0082 & 0.0042 & -0.0665 & -0.2142 & -0.0227 & -0.0208 \\
\hline 4 & -0.0574 & -0.2269 & 0.0055 & -0.0004 & -0.0401 & -0.1885 & 0.0294 & 0.0336 & -0.099 & -0.3132 & -0.0057 & -0.0265 \\
\hline 5 & -0.0557 & -0.2826 & -0.0091 & -0.0095 & -0.0503 & -0.2388 & 0.0438 & 0.0774 & & & & \\
\hline 6 & -0.0503 & -0.3329 & -0.0285 & -0.038 & & & & & & & & \\
\hline 7 & & & & & & & & & & & & \\
\hline Test & Males & Males & NR & NR & Males & Males & NR & NR & Whites & Whites & NR & NR \\
\hline Result & FOSD & SOSD $* *$ & & & FOSD & SOSD & & & FOSD* & SOSD* & & \\
\hline
\end{tabular}

Notes:1. US: $\mathrm{N}=530$ for males \& 529 for females for Home and Environment; N=402 for males \& 321 for females for Work. UK: N=846 for males \& 843 for females for Home and Environment; N=656 for males \& 587 for females for Work 
Another way to compare multi-dimensional wellbeing between countries is to look at the respective within-country rankings of capabilities. That is, within a country, on average, in which dimensions do people feel they have relatively high levels of capability, and are such rankings consistent across countries. Without any strong priors about the differences that might emerge, the results in Table 3 suggest a perhaps surprising degree of similarity between the two countries, albeit with a couple of notable exceptions. For the most part, the extent to which people are able to perform tasks or access and receive services are within one or two ranks of each of other. That said, there are a couple of rather larger differences for dimensions related to criminal justice and health, differences that might be at least partially attributed to institutional differences in the supply of these services.

In the UK, people rank their ability to be treated by a doctor or nurse higher, relative to other capacities, than is the case in the USA. This suggests that the universal system of public finance that accounts for roughly nine-tenths of health care in the UK is providing greater effective access to those who would otherwise find access to health-care difficult-i.e. those on low incomes.

There are also differences with respect to criminal justice. In the USA, respondents rank higher their ability to be helped by the police, but rank lower their ability to get help from a legal representative, compared with counterpart rankings in the UK. Legal representation is generally financed through private sector market mechanisms in both countries, though the UK also has a reasonably well developed system of legal aid which could contribute to a higher within-country ranking. By contrast, police services in both countries, as in most around the world, are generally provided as a publicly financed service, so it is possible that the higher internal ranking reflects some other cultural difference, perhaps, for example, a more developed sense of customer ethos, though it is impossible to ascertain from the data.

Another finding worth noting is that ability to get rubbish cleared is ranked highest by US respondents. It is also very highly ranked by respondents from the UK, which suggests that this is not an artefact. From the data we can only speculate but it seems that a constellation of factors might be important here. Clearing waste is essential but not very complicated; by contrast, if not cleared, it can give rise to a salient problem. In such a case, it would not be difficult to identify the local political representatives responsible in either country. In their overview of the economics of service provision, Keefer and Khemanai (2005) demonstrate that effective political competition can play a major role in the provision of services for the electorate and we suggest that this finding reflects their insight; in both countries the nature of the service is such that political competition is indeed relatively effective.

An individual's wellbeing is a function not just of their resources, in our framework, but also of a variety of personal attributes, including non-cognitive skills, and we therefore estimate 
Table 3 Ranks of individual capabilities by country

\begin{tabular}{|c|c|c|}
\hline What people are able to do & $U S$ & $U K$ \\
\hline Get my rubbish cleared away & 1 & 4 \\
\hline Practice my religious beliefs & 2 & 3 \\
\hline Make use of banking and personal finance services & 3 & 1 \\
\hline Keep a pet or animal at home with ease if I so wish & 4 & 8 \\
\hline Get to a range of shops & 5 & 2 \\
\hline Get help from the police $*$ & 6 & 11 \\
\hline Am treated where I live as an equal (and not discriminated against) & 7 & 9 \\
\hline Express my political views when I wish & 8 & 7 \\
\hline Get to places I need to without difficulty & 9 & 10 \\
\hline Visit parks or countryside whenever I want $*$ & 10 & 5 \\
\hline Be treated by a doctor or nurse $*$ & 11 & 6 \\
\hline Walk in my local neighbourhood safely at night & 12 & 14 \\
\hline Be treated as an equal (and not discriminated against) by people at work & 13 & 13 \\
\hline Get trades people or the landlord to help fix problems in the house & 14 & 15 \\
\hline Use my talents and skills at work & 15 & 17 \\
\hline Find work when I need to & 16 & 18 \\
\hline Socialise with others in family as I would wish & 17 & 19 \\
\hline Find a home suitable for my needs & 18 & 16 \\
\hline Feel valued and loved & 19 & 21 \\
\hline Work under a good manager at the moment & 20 & 24 \\
\hline Socialise at work * & 21 & 27 \\
\hline Share domestic tasks with the household fairly & 22 & 23 \\
\hline Enjoy the kinds of personal relationships that I want & 23 & 22 \\
\hline Make ends meet & 24 & 20 \\
\hline Work in an environment that has little pollution & 25 & 25 \\
\hline Get help from a solicitor $*$ & 26 & 12 \\
\hline Achieve a good work life balance & 27 & 26 \\
\hline Take part in local social events & 28 & 28 \\
\hline Be promoted or recognised at work & 29 & 29 \\
\hline
\end{tabular}

Notes: 1 . Rank 1 indicates the highest average score for that country's responses; rank 29 indicates the lowest average score; 2 . Rankings derived from national average ratings; differences of 5 or more are marked $* ; 3$. Spearman's rank-correlation coefficient $\rho=0.899$. Kendall's rank-correlation coefficient $\tau_{a}=-0.052$. 
such models, using both ordered probit and OLS models. A variety of results are reported in Table 4. We expected the role of non-cognitive skills to be relatively similar between countries and, broadly speaking, find this to be the case. Treating income, for these purposes, as an indicator of consumer welfare, we find that, controlling for education, the ability to plan ahead is the only such skill that is statistically significant in our US sample, while the ability to take guidance, and being able to provide leadership, are the only ones which are positively and statistically significant in our UK sample. However, in models of life satisfaction, a number of variables appear to be significant, including ability to take guidance, knowing what one likes and being good at sports. It is quite possible, of course, that the significance of the non-cognitive skill variables in the life satisfaction regressions is driven by endogeneities due to reporting styles or reverse causality; this is not necessarily a story of causality. Our observation is simply that it is interesting that inclusion of these variables enhances the predictive power of the life satisfaction regressions. ${ }^{19}$

Finally, in Table 5(a) and (b) we offer some evidence relating to the production of activities themselves. For caring, cooking, DIY, drinking, and volunteering, we present models in which involvement in these activities depends on resources and the ability to convert these resources into those activities. Taking log income as the main measure of resource gives rise to two models in which the coefficient on income is negative suggesting these are activity counter-parts to inferior goods. A variety of personal characteristics are also relevant in these models including formal education in models of volunteering in both countries. Controlling for education as well as these other personal factors, there is evidence that non-cognitive skills are important at least in some cases and possibly more so in the US than in the UK, which cautions against assuming that the results found in the US by Heckman and colleagues are going to be identical in other countries. In Table 5b, non-cognitive skills, as we measure them in this dataset, are as often related to activity involvement as is income. However, when we estimate models of indices of leisure involvement, the effects of non-cognitive skills are significant in all models, whereas those of resources are not significant in any. The non-significant impact of income on leisure activity involvement undoubtedly reflects the low cost of the activities for which we have data, but the strength of the non-cognitive skills highlights the fact that for some activities which give people pleasure these

\footnotetext{
${ }^{19}$ It is difficult to adequately explore causal relations such as this in our cross-sectional pilot data, but should be relatively straightforward if data such as that proposed here were rolled out in a panel setting. That said, we did find some very tentative evidence to support causality here. We created an index $N C$ from binary variables $s_{i}$ constructed from our non-cognitive skills data, so that $N C=\sum_{j=1}^{j=11} s_{j}$. This variable was then instrumented for, using data on whether or not individuals were engaged in particular activities yesterday (see note 1 to Table 4 for further details). In the resulting 2SLS regressions, the non-cognitive skills index was found to be statistically significant at the 5\% level in the USA. In the UK, the instruments were found to be rather weak and though the non-cognitive skills index coefficient remained positive after instrumentation, it was no longer statistically significant.
} 
UK

Life Satisfaction

\begin{tabular}{|c|c|c|c|c|c|c|c|c|c|c|c|c|}
\hline & \multicolumn{2}{|c|}{ Income } & \multicolumn{4}{|c|}{ Life Satisfaction } & \multicolumn{2}{|c|}{ Income } & \multicolumn{4}{|c|}{ Life Satisfaction } \\
\hline & OLS & OLS & O. Probit & O. Probit & O. Probit & 2SLS & OLS & OLS & O. Probit & O. Probit & O. Probit & 2SLS \\
\hline \multicolumn{13}{|l|}{ Non-cognitive skills } \\
\hline Can take Guidance & $\begin{array}{l}-0.010 \\
(0.024)\end{array}$ & $\begin{array}{l}-0.013 \\
(0.022)\end{array}$ & $\begin{array}{l}0.111 \text { *** } \\
(0.032)\end{array}$ & $\begin{array}{l}0.099 * * * * \\
(0.033)\end{array}$ & & & $\begin{array}{l}0.023 \\
(0.017)\end{array}$ & $\begin{array}{l}0.034 * * \\
(0.016)\end{array}$ & $\begin{array}{l}0.132 * * * \\
(0.025)\end{array}$ & $\begin{array}{l}0.109 * * * \\
(0.027)\end{array}$ & & \\
\hline See other views & $\begin{array}{l}-0.032 \\
(0.025)\end{array}$ & $\begin{array}{l}-0.009 \\
(0.023)\end{array}$ & $\begin{array}{l}-0.035 \\
(0.028)\end{array}$ & $\begin{array}{l}-0.035 \\
(0.030)\end{array}$ & & & $\begin{array}{l}-0.028^{*} \\
(0.016)\end{array}$ & $\begin{array}{l}-0.036^{* *} \\
(0.015)\end{array}$ & $\begin{array}{l}-0.047 * \\
(0.024)\end{array}$ & $\begin{array}{l}-0.056^{* *} \\
(0.025)\end{array}$ & & \\
\hline Can plan future & $\begin{array}{l}0.072 * * * \\
(0.019)\end{array}$ & $\begin{array}{l}0.041 * * \\
(0.018)\end{array}$ & $\begin{array}{l}0.142 * * * \\
(0.025)\end{array}$ & $\begin{array}{l}0.118 \text { *** } \\
(0.027)\end{array}$ & & & $\begin{array}{l}0.056 \text { *** } \\
(0.013)\end{array}$ & $\begin{array}{l}0.020 \\
(0.013)\end{array}$ & $\begin{array}{l}0.223 * * * \\
(0.023)\end{array}$ & $\begin{array}{l}0.186 \text { *** } \\
(0.024)\end{array}$ & & \\
\hline Know what I like & $\begin{array}{l}0.025 \\
(0.033)\end{array}$ & $\begin{array}{l}0.023 \\
(0.028)\end{array}$ & $\begin{array}{l}0.071^{*} \\
(0.038)\end{array}$ & $\begin{array}{l}0.074^{*} \\
(0.039)\end{array}$ & & & $\begin{array}{l}0.004 \\
(0.021)\end{array}$ & $\begin{array}{l}0.007 \\
(0.020)\end{array}$ & $\begin{array}{l}0.089 * * * \\
(0.033)\end{array}$ & $\begin{array}{l}0.104 * * * \\
(0.032)\end{array}$ & & \\
\hline Know strengths \& weaknesses & $\begin{array}{l}-0.006 \\
(0.033)\end{array}$ & $\begin{array}{l}-0.023 \\
(0.029)\end{array}$ & $\begin{array}{l}-0.065^{*} \\
(0.039)\end{array}$ & $\begin{array}{l}-0.090 * * \\
(0.041)\end{array}$ & & & $\begin{array}{l}-0.004 \\
(0.024)\end{array}$ & $\begin{array}{l}-0.000 \\
(0.023)\end{array}$ & $\begin{array}{l}-0.093 * * * \\
(0.035)\end{array}$ & $\begin{array}{l}-0.066^{*} \\
(0.034)\end{array}$ & & \\
\hline Have 5 year plan & $\begin{array}{l}0.011 \\
(0.016)\end{array}$ & $\begin{array}{l}-0.002 \\
(0.015)\end{array}$ & $\begin{array}{l}0.086 * * * \\
(0.020)\end{array}$ & $\begin{array}{l}0.077 \text { *** } \\
(0.020)\end{array}$ & & & $\begin{array}{l}-0.003 \\
(0.010)\end{array}$ & $\begin{array}{l}-0.011 \\
(0.010)\end{array}$ & $\begin{array}{l}0.082 * * * \\
(0.016)\end{array}$ & $\begin{array}{l}0.061 * * * \\
(0.016)\end{array}$ & & \\
\hline Can provide leadership & $\begin{array}{l}0.043 * * \\
(0.019)\end{array}$ & $\begin{array}{l}0.019 \\
(0.019)\end{array}$ & & & & & $\begin{array}{l}0.045^{* * *} * \\
(0.011)\end{array}$ & $\begin{array}{l}0.025^{* *} \\
(0.011)\end{array}$ & & & & \\
\hline Good at sports & $\begin{array}{l}0.008 \\
(0.013)\end{array}$ & $\begin{array}{l}0.000 \\
(0.013)\end{array}$ & $\begin{array}{l}0.060^{* * * *} \\
(0.016)\end{array}$ & $\begin{array}{l}0.052^{* * *} * \\
(0.018)\end{array}$ & & & $\begin{array}{l}0.012 \\
(0.008)\end{array}$ & $\begin{array}{l}-0.002 \\
(0.008)\end{array}$ & $\begin{array}{l}0.049 * * * \\
(0.013)\end{array}$ & $\begin{array}{l}0.036^{\text {*** }} \\
(0.015)\end{array}$ & & \\
\hline Non-cognitive skills index & & & & & $\begin{array}{l}0.182 * * * \\
(0.023)\end{array}$ & $\begin{array}{l}0.373^{* *} \\
(0.149)\end{array}$ & & & & & $\begin{array}{l}0.184 * * * \\
(0.016)\end{array}$ & $\begin{array}{l}0.218 \\
(0.232)\end{array}$ \\
\hline \multicolumn{13}{|l|}{ Controls } \\
\hline Income & & & & $\begin{array}{l}0.028 \\
(0.063)\end{array}$ & $\begin{array}{l}0.061 \\
(0.060)\end{array}$ & $\begin{array}{l}0.105 \\
(0.107)\end{array}$ & & & & $\begin{array}{l}0.065 \\
(0.052)\end{array}$ & $\begin{array}{l}0.102 * * \\
(0.051)\end{array}$ & $\begin{array}{l}0.206^{*} \\
(0.108)\end{array}$ \\
\hline Unemployed & & $\begin{array}{l}-0.348^{* * * *} \\
(0.105)\end{array}$ & & $\begin{array}{l}-0.495 * * * \\
(0.162)\end{array}$ & $\begin{array}{l}-0.533^{* * * *} \\
(0.149)\end{array}$ & $\begin{array}{l}-1.003 * * * \\
(0.294)\end{array}$ & & $\begin{array}{l}-0.527 * * * \\
(0.103)\end{array}$ & & $\begin{array}{l}-0.589 * * * \\
(0.157)\end{array}$ & $\begin{array}{l}-0.709 * * * \\
(0.139)\end{array}$ & $\begin{array}{l}-1.354 * * * * \\
(0.268)\end{array}$ \\
\hline Married or partnered & & $\begin{array}{l}0.250 * * * \\
(0.071)\end{array}$ & & $\begin{array}{l}0.219 * * \\
(0.094)\end{array}$ & $\begin{array}{l}0.314 * * * \\
(0.092)\end{array}$ & $\begin{array}{l}0.544 * * * \\
(0.182)\end{array}$ & & $\begin{array}{l}0.169 * * * \\
(0.044)\end{array}$ & & $\begin{array}{l}0.096 \\
(0.072)\end{array}$ & $\begin{array}{l}0.186^{* * *} \\
(0.072)\end{array}$ & $\begin{array}{l}0.347 * * \\
(0.151)\end{array}$ \\
\hline Health & & $\begin{array}{l}0.780 * * * \\
(0.164)\end{array}$ & & $\begin{array}{l}0.803 * * * \\
(0.223)\end{array}$ & $\begin{array}{l}1.117 * * * \\
(0.221)\end{array}$ & $\begin{array}{l}2.181 * * * \\
(0.440)\end{array}$ & & $\begin{array}{l}0.561 * * * \\
(0.093)\end{array}$ & & $\begin{array}{l}1.142 * * * \\
(0.167)\end{array}$ & $\begin{array}{l}1.807 * * * \\
(0.161)\end{array}$ & $\begin{array}{l}3.520 * * * \\
(0.336)\end{array}$ \\
\hline Education & & Yes & & Yes & Yes & Yes & & Yes & & Yes & Yes & Yes \\
\hline Sex, Ethnicity, Age, $\mathrm{Age}^{2} \&$ Personality & & Yes & & Yes & Yes & Yes & & Yes & & Yes & Yes & Yes \\
\hline $\mathrm{N}$ & 658 & 658 & 678 & 658 & 658 & 658 & 1,052 & 1,038 & 1,086 & 1,038 & 1,038 & 1,038 \\
\hline AIC & 1634.247 & 1484.299 & 2682.886 & 2565.519 & 2601.48 & & 2277.573 & 2085.178 & 4137.934 & 3879.681 & 4048.55 & \\
\hline Adj R-Sq (OLS)/Pseudo R-Sq (OProbit) & 0.0693 & 0.2731 & 0.0878 & 0.1088 & 0.0917 & & 0.0888 & 0.2263 & 0.1307 & 0.1532 & 0.1131 & \\
\hline
\end{tabular}
exercising and spending time with children. The F-stats in the first-stage regressions are 40.9 for the US and 14.9 for the UK, indicating sufficiently strong instruments. In another, unreported, 2 SLS regression, the four daily activities themselves were used as instrumental variables. The p-values for the instrumented non-cognitive skills index were 0.017 for the US and 0.245 for the UK. The F-stats in the first-stage regressions were 10.4 for the US, indicating borderline sufficiently strong instruments, but only 4.0 for the UK. In the corresponding tests for overidentifying restrictions, the null hypothesis of no misspecification was not rejected in either case (p-values of 0.412 for the US and 0.318 for the UK); 2. Income variable is adjusted for household composition using the Modified OECD equivalence scale. 
Table 5a: Activity Models

\begin{tabular}{|c|c|c|c|c|c|c|c|c|c|c|}
\hline & \multicolumn{2}{|c|}{$\begin{array}{l}\text { Caring } \\
\end{array}$} & \multicolumn{2}{|c|}{ Cooking } & \multicolumn{2}{|c|}{ 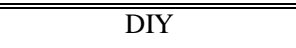 } & \multicolumn{2}{|c|}{ Drinking } & \multicolumn{2}{|c|}{ Volunteering } \\
\hline & USA & UK & USA & UK & USA & UK & USA & UK & USA & UK \\
\hline \multicolumn{11}{|c|}{ Human development indicators } \\
\hline Log Income & $\begin{array}{c}0.051 \\
(0.094)\end{array}$ & $\begin{array}{c}-0.274 * * * \\
(0.085)\end{array}$ & $\begin{array}{c}-0.167 * * \\
(0.070)\end{array}$ & $\begin{array}{l}-0.088 \\
(0.061)\end{array}$ & $\begin{array}{c}0.052 \\
(0.091)\end{array}$ & $\begin{array}{c}0.004 \\
(0.073)\end{array}$ & $\begin{array}{c}0.190 * * \\
(0.079)\end{array}$ & $\begin{array}{l}0.211 * * * \\
(0.068)\end{array}$ & $\begin{array}{l}-0.023 \\
(0.085)\end{array}$ & $\begin{array}{c}0.003 \\
(0.088)\end{array}$ \\
\hline Health & $\begin{array}{l}-0.080 \\
(0.356)\end{array}$ & $\begin{array}{l}-0.235 \\
(0.214)\end{array}$ & $\begin{array}{c}0.300 \\
(0.245)\end{array}$ & $\begin{array}{c}0.379 * * \\
(0.174)\end{array}$ & $\begin{array}{l}-0.221 \\
(0.299)\end{array}$ & $\begin{array}{l}0.563^{* *} \\
(0.259)\end{array}$ & $\begin{array}{c}0.121 \\
(0.260)\end{array}$ & $\begin{array}{l}-0.101 \\
(0.188)\end{array}$ & $\begin{array}{l}0.624 * \\
(0.348)\end{array}$ & $\begin{array}{l}-0.275 \\
(0.252)\end{array}$ \\
\hline Education & $\begin{array}{c}0.024 \\
(0.197)\end{array}$ & $\begin{array}{l}-0.034 \\
(0.124)\end{array}$ & $\begin{array}{c}0.002 \\
(0.126)\end{array}$ & $\begin{array}{l}0.025 \\
(0.085)\end{array}$ & $\begin{array}{c}0.037 \\
(0.177)\end{array}$ & $\begin{array}{l}-0.026 \\
(0.117)\end{array}$ & $\begin{array}{l}-0.180 \\
(0.135)\end{array}$ & $\begin{array}{c}0.028 \\
(0.092)\end{array}$ & $\begin{array}{l}0.307 * \\
(0.173)\end{array}$ & $\begin{array}{r}0.279 * * \\
(0.140)\end{array}$ \\
\hline Non-cognitive skills index & $\begin{array}{l}0.008 \\
(0.005)\end{array}$ & $\begin{array}{c}0.003 \\
(0.003)\end{array}$ & $\begin{array}{c}0.016^{* * * *} \\
(0.003)\end{array}$ & $\begin{array}{c}0.008 * * * \\
(0.003)\end{array}$ & $\begin{array}{c}0.010^{* *} \\
(0.005)\end{array}$ & $\begin{array}{c}0.003 \\
(0.004)\end{array}$ & $\begin{array}{l}-0.005 \\
(0.004)\end{array}$ & $\begin{array}{l}-0.002 \\
(0.003)\end{array}$ & $\begin{array}{c}0.020^{* * *} \\
(0.004)\end{array}$ & $\begin{array}{c}0.006 \\
(0.004)\end{array}$ \\
\hline \multicolumn{11}{|c|}{$\begin{array}{l}\text { Personal Characteristics and Social } \\
\text { Resource Indicators }\end{array}$} \\
\hline Unemployed & $\begin{array}{l}0.463 * \\
(0.254)\end{array}$ & $\begin{array}{l}-0.409 \\
(0.299)\end{array}$ & $\begin{array}{l}0.293^{*} \\
(0.166)\end{array}$ & $\begin{array}{c}0.273 \\
(0.179)\end{array}$ & $\begin{array}{c}0.082 \\
(0.236)\end{array}$ & $\begin{array}{c}0.066 \\
(0.267)\end{array}$ & $\begin{array}{l}-0.047 \\
(0.193)\end{array}$ & $\begin{array}{c}0.263 \\
(0.193)\end{array}$ & $\begin{array}{l}0.408^{*} \\
(0.209)\end{array}$ & $\begin{array}{c}0.136 \\
(0.262)\end{array}$ \\
\hline $\begin{array}{l}\text { Married } \\
\text { or Partnered }\end{array}$ & $\begin{array}{l}-0.212 \\
(0.177)\end{array}$ & $\begin{array}{l}-0.168 \\
(0.135)\end{array}$ & $\begin{array}{c}0.288 * * \\
(0.116)\end{array}$ & $\begin{array}{l}0.177^{*} \\
(0.090)\end{array}$ & $\begin{array}{c}0.491 * * * \\
(0.166)\end{array}$ & $\begin{array}{l}-0.011 \\
(0.123)\end{array}$ & $\begin{array}{c}0.148 \\
(0.131)\end{array}$ & $\begin{array}{c}0.246^{* *} \\
(0.096)\end{array}$ & $\begin{array}{l}-0.290 * \\
(0.154)\end{array}$ & $\begin{array}{l}-0.125 \\
(0.140)\end{array}$ \\
\hline Male & $\begin{array}{l}-0.103 \\
(0.167)\end{array}$ & $\begin{array}{l}-0.032 \\
(0.123)\end{array}$ & $\begin{array}{c}-0.331 * * * \\
(0.103)\end{array}$ & $\begin{array}{c}-0.344 * * * \\
(0.082)\end{array}$ & $\begin{array}{c}0.445 * * * \\
(0.136)\end{array}$ & $\begin{array}{c}0.525 * * * \\
(0.117)\end{array}$ & $\begin{array}{c}0.405 * * * \\
(0.115)\end{array}$ & $\begin{array}{c}0.183 * * \\
(0.088)\end{array}$ & $\begin{array}{c}0.122 \\
(0.133)\end{array}$ & $\begin{array}{l}-0.003 \\
(0.130)\end{array}$ \\
\hline White & $\begin{array}{l}-0.179 \\
(0.202)\end{array}$ & $\begin{array}{c}0.064 \\
(0.392)\end{array}$ & $\begin{array}{c}-0.004 \\
(0.130)\end{array}$ & $\begin{array}{l}-0.072 \\
(0.225)\end{array}$ & $\begin{array}{c}0.027 \\
(0.184)\end{array}$ & $\begin{array}{c}-0.242 \\
(0.321)\end{array}$ & $\begin{array}{c}-0.152 \\
(0.144)\end{array}$ & $\begin{array}{l}-0.010 \\
(0.249)\end{array}$ & $\begin{array}{c}0.088 \\
(0.174)\end{array}$ & $\begin{array}{l}-0.186 \\
(0.320)\end{array}$ \\
\hline Controls for age & Yes & Yes & Yes & Yes & Yes & Yes & Yes & Yes & Yes & Yes \\
\hline $\mathrm{N}$ & 658 & 1038 & 658 & 1038 & 658 & 1038 & 658 & 1038 & 658 & 1038 \\
\hline AIC & 305.1044 & 555.5909 & 873.8267 & 1405.254 & 468.1359 & 629.5146 & 694.2037 & 1188.98 & 470.4305 & 494.6455 \\
\hline Pseudo R-Sq. & 0.0598 & 0.0793 & 0.0761 & 0.0445 & 0.0818 & 0.0794 & 0.0493 & 0.0311 & 0.0848 & 0.0374 \\
\hline
\end{tabular}

NOTES: 1. Controls included for personality; 2. Income variable is adjusted for household composition using the Modified OECD equivalence scale; 3 . Education is a binary variable indicating an above high school education; 4 . Non-cognitive skills index is obtained by summing across all eleven non-cognitive skills listed in Table A2; 5. Controls for age include age and age squared. 
Table 5b: Leisure Activity Models

\begin{tabular}{|c|c|c|c|c|c|c|c|c|}
\hline & \multicolumn{2}{|c|}{$\begin{array}{l}\text { Logged Out of Home } \\
\text { Leisure (OLS) }\end{array}$} & \multicolumn{2}{|c|}{$\begin{array}{c}\text { Out of Home Leisure } \\
\text { (Ordered Probit) }\end{array}$} & \multicolumn{2}{|c|}{$\begin{array}{c}\text { Logged Indoor Leisure } \\
\text { (OLS) }\end{array}$} & \multicolumn{2}{|c|}{$\begin{array}{c}\text { Indoor Leisure (Ordered } \\
\text { Probit) }\end{array}$} \\
\hline & USA & UK & USA & UK & USA & UK & USA & UK \\
\hline Human development indicator & & & & & & & & \\
\hline Log Income & $\begin{array}{l}-0.003 \\
(0.029)\end{array}$ & $\begin{array}{c}0.013 \\
(0.023)\end{array}$ & $\begin{array}{l}-0.002 \\
(0.060)\end{array}$ & $\begin{array}{c}0.032 \\
(0.053)\end{array}$ & $\begin{array}{c}0.009 \\
(0.025)\end{array}$ & $\begin{array}{l}-0.004 \\
(0.022)\end{array}$ & $\begin{array}{c}0.024 \\
(0.059)\end{array}$ & $\begin{array}{l}-0.021 \\
(0.049)\end{array}$ \\
\hline Health & $\begin{array}{l}0.165^{*} \\
(0.095)\end{array}$ & $\begin{array}{l}0.117 * \\
(0.061)\end{array}$ & $\begin{array}{l}0.363^{*} \\
(0.209)\end{array}$ & $\begin{array}{l}0.322^{*} \\
(0.168)\end{array}$ & $\begin{array}{c}0.100 \\
(0.087)\end{array}$ & $\begin{array}{c}0.009 \\
(0.063)\end{array}$ & $\begin{array}{c}0.189 \\
(0.199)\end{array}$ & $\begin{array}{l}-0.022 \\
(0.143)\end{array}$ \\
\hline Education & $\begin{array}{c}0.058 \\
(0.051)\end{array}$ & $\begin{array}{c}0.027 \\
(0.033)\end{array}$ & $\begin{array}{c}0.130 \\
(0.108)\end{array}$ & $\begin{array}{c}0.065 \\
(0.076)\end{array}$ & $\begin{array}{l}0.080^{*} \\
(0.043)\end{array}$ & $\begin{array}{l}-0.006 \\
(0.029)\end{array}$ & $\begin{array}{l}0.198^{*} \\
(0.103)\end{array}$ & $\begin{array}{c}0.008 \\
(0.068)\end{array}$ \\
\hline $\begin{array}{l}\text { Non-cognitive skills index } \\
\text { Personal Characteristics and } \\
\text { Social Resource Indicators }\end{array}$ & $\begin{array}{c}0.009 * * * \\
(0.001)\end{array}$ & $\begin{array}{c}0.004 * * * \\
(0.001)\end{array}$ & $\begin{array}{c}0.020 * * * \\
(0.003)\end{array}$ & $\begin{array}{c}0.011 * * * \\
(0.002)\end{array}$ & $\begin{array}{c}0.003 * * \\
(0.001)\end{array}$ & $\begin{array}{c}0.003 * * * \\
(0.001)\end{array}$ & $\begin{array}{c}0.006 * * \\
(0.003)\end{array}$ & $\begin{array}{c}0.008 * * * \\
(0.002)\end{array}$ \\
\hline Unemployed & $\begin{array}{l}-0.005 \\
(0.073)\end{array}$ & $\begin{array}{c}0.016 \\
(0.069)\end{array}$ & $\begin{array}{l}-0.021 \\
(0.158)\end{array}$ & $\begin{array}{c}0.047 \\
(0.168)\end{array}$ & $\begin{array}{l}0.100 * \\
(0.056)\end{array}$ & $\begin{array}{c}0.072 \\
(0.058)\end{array}$ & $\begin{array}{l}0.263^{*} \\
(0.138)\end{array}$ & $\begin{array}{c}0.165 \\
(0.137)\end{array}$ \\
\hline $\begin{array}{l}\text { Married } \\
\text { or Partnered }\end{array}$ & $\begin{array}{l}-0.012 \\
(0.046)\end{array}$ & $\begin{array}{c}0.003 \\
(0.034)\end{array}$ & $\begin{array}{l}-0.022 \\
(0.096)\end{array}$ & $\begin{array}{c}0.002 \\
(0.080)\end{array}$ & $\begin{array}{c}0.055 \\
(0.039)\end{array}$ & $\begin{array}{c}0.047 \\
(0.031)\end{array}$ & $\begin{array}{c}0.208 * * \\
(0.091)\end{array}$ & $\begin{array}{l}0.146 * * \\
(0.070)\end{array}$ \\
\hline White & $\begin{array}{c}0.031 \\
(0.056)\end{array}$ & $\begin{array}{c}0.022 \\
(0.087)\end{array}$ & $\begin{array}{c}0.047 \\
(0.120)\end{array}$ & $\begin{array}{c}0.074 \\
(0.217)\end{array}$ & $\begin{array}{c}0.031 \\
(0.047)\end{array}$ & $\begin{array}{l}0.188^{*} \\
(0.101)\end{array}$ & $\begin{array}{c}0.013 \\
(0.112)\end{array}$ & $\begin{array}{c}0.296 \\
(0.253)\end{array}$ \\
\hline Controls for age and sex & Yes & Yes & Yes & Yes & Yes & Yes & Yes & Yes \\
\hline $\mathrm{N}$ & 658 & 1,038 & 658 & 1,038 & 658 & 1,038 & 658 & 1,038 \\
\hline AIC & 1059.102 & 1498.323 & 1852.807 & 2455.681 & 777.2892 & 1266.016 & 2043.875 & 3147.753 \\
\hline R-Sq / Pseudo R-Sq & 0.1004 & 0.0503 & 0.0379 & 0.0230 & 0.0503 & 0.0423 & 0.0177 & 0.0148 \\
\hline
\end{tabular}

NOTES: 1. Out of Home Leisure index is obtained by summing the binary indicators for activities related to going out, i.e. exercising; visiting park or countryside; visiting cinema, concert, gallery or museum; other outdoor activities; and socialising; Indoor Leisure index is obtained by summing the binary indicators for activities related to indoor activities, i.e. intimate relations; listening to music; playing music; reading; and watching television; 3. Controls included for personality; 4. Income variable is adjusted for household composition using the Modified OECD equivalence scale; 5 . Education is a binary variable indicating an above high school education; 6 Non-cognitive skills index is obtained by summing across all eleven non-cognitive skills listed in Table A2; 7. Controls for age include age and age squared. 
may play a role that is much more significant than income. The important and widely cited findings of Heckman and colleagues have tended to be couched in terms of long term benefits to individuals and society, such as through the reduction of criminal behaviour (rather than, say, any increase in IQ). These findings echo those and suggest that non-cognitive skills could be rather material contributors to a person's own life quality, and therefore merit particular attention in the design of, and support for, schooling and parenting regimes.

\section{Discussion and Conclusions}

While income measures the opportunities people have to consume and save, there is a growing consensus both within and outside economics that the effects of economic activity on human wellbeing outcomes should be monitored directly. Various initiatives and commissions (e.g. Stiglitz, Sen and Fitoussi (2009)) have drawn on developments in welfare and behavioural economics but implementation has been limited by the availability of data. In this paper, we developed a framework for understanding wellbeing, drawing closely on Sen's contributions to welfare economics, as well as the economic literature on life satisfaction, and used it to generate novel data consistent with all the components of his theory. The approach in practice naturally gives rise to a number of ordinal measures and, to compare these, we also developed an approach to first and second order stochastic dominance that is suitable for such variables, on a dimension by dimension basis. Using these data and tests, we have identified gender and ethnic differences, in multiple dimensions, concerning what people are able to do. We then presented various analyses to shed light, inter alia, on dimensions associated with life satisfaction, including non-cognitive skills, and the relative ranking of various capabilities within the USA and UK.

Our primary aim has been to show that it is possible to 'go beyond GDP' in a manner consistent with economic theory, and in principle the resulting measures could be used to illuminate the distribution and production of wellbeing. As with any approach, our focus on the kind of data that are used in household survey design has its pros and cons but we believe that this exercise demonstrates that Sen's theory is empirically operational and that early concerns about the lack of data can be overcome. In addition, we believe our estimation of his equations indicates that they can support analyses which incorporate aspects of wellbeing that are not so evident from a focus on income alone.

While our particular empirical results are, in a sense, secondary to this aim they nonetheless demonstrate some potentially important points. If we look at inequality from a multi-dimensional perspective, the evidence from comparisons by gender and ethnicity suggests that inequalities to do with environment may be as marked as those to do with income, at least in the USA. Our life satisfaction and leisure involvement models lend further weight to the growing recognition within economics of the important role of non-cognitive skills. They are 
found not only to be significantly associated with engagement in leisure activities, but also to add significant predictive power to models of experience utility.

Turning to the limitations of this study, perhaps the most significant are problems to do with the crosssectional nature of the data. However, the econometric problems that arise from this illustration could, in principle, be addressed with panel data. ${ }^{20} \mathrm{We}$ have also sought to avoid direct country comparisons here and have confined ourselves to international comparisons based on intra-country analyses. In principle, the problems of direct international comparisons have been addressed for income using the concept of purchasing power parity, and for life satisfaction through the use of vignettes, but the question remains open for multi-dimensional indicators based on household survey type questions. These caveats notwithstanding, we believe this paper offers a valuable blueprint for policy-makers wanting to go 'beyond GDP' by demonstrating how they can construct and analyse the relevant indicators in a theoretically principled fashion. For researchers it shows how Sen's approach to the economics of wellbeing can be given a full and direct operationalization using standard economic analyses applied to appropriate data.

\section{References}

Alkire, S. and Foster, J. (2011), "Counting and Multidimensional Poverty Measurement," Journal of Public Economics, 95, 476-487.

Anand, P., Krishnakumar, J. and Tran, N-B. (2011), "Measuring welfare: Latent variable models for happiness and capabilities in the presence of unobservable heterogeneity," Journal of Public Economics, 95, 205215 .

Anand, P., Santos, C. and Smith, R., (2009), "The measurement of capabilities," Chapter 16 in Arguments for a Better World - Essays in Honor of Amartya Sen, (eds) Basu, K. and Kanbur, R., Oxford, Oxford University Press.

Anderson, G. (1996), "Nonparametric tests of stochastic dominance in income distributions,” Econometrica 64, 1183-1193.

Anderson, G., Teng Wah, L. and Anand, P. (2014), "Multi-Dimensional Wellbeing Assessment: A General Method for Index Construction with an Application to Multivariate Deprivation,” Working Paper 524, Department of Economics, University of Toronto.

Atkinson, A. and Bourguignon, F. (1982), "The comparison of multi-dimensioned distributions of economic status," Review of Economic Studies 49, 183-201.

\footnotetext{
${ }^{20}$ Alternatively, embedding within randomised control trials is feasible. An early version of some of our indicators has been used, for example, in an Oxford based clinical trial concerning the efficacy of mental health interventions - see Simon et al (2013).
} 
Bargain, O., Decoster, A. Dolls, M., Neumann, D., Peichl, A. and Siegloch, S., (2013), "Welfare, Labor Supply and Heterogeneous Preferences: Evidence for Europe and the US”, Social Choice and Welfare, 41 (4), 789-817.

Basu, K. and Kanbur, R. (2009), “Arguments for a Better World,” Oxford, Oxford University Press.

Becker, G. S., Philipson, T. J. and Soares, R. R. (2005), "The Quantity and Quality of Life and the Evolution of World Inequality", American Economic Review, 95, 277-91.

Benjamin, D., Heffetz, O., Kimball, M. and Szembrot, N. (2014), "Beyond Happiness and Satisfaction: Toward Well-Being Indices Based on Stated Preference," American Economic Review, 104, 2698-2735.

Blanchflower, D. G., and Oswald, A. J. (2004), "Well-being over time in Britain and the USA," Journal of Public Economics, 88, 1359-1386.

Borghans, L., Duckworth, A., Heckman, J. and ter Weel, B. (2008), "The Economics and Psychology of Personality Traits," Journal of Human Resources, 43, 972-1059.

Brandolini, A., and D’Alessio, G. (1998, October), "Measuring well-being in the functioning space," Discussion Paper, Bank of Italy, Rome.

Clark, E., and Senik, C. (2011), "Is happiness different from flourishing? Cross-country evidence from the ESS," Revue d'économie politique, 121, 17-34.

Cunha, F. and Heckman, J. (2008), "Formulating, Identifying and Estimating the Technology of Cognitive and Noncognitive Skill Formation,” Journal of Human Resources, 43, 738-782.

Cunha, F., Heckman, J., and Schennach, S. (2010), "Estimating the technology of cognitive and noncognitive skill formation," Econometrica, 78, 883-931.

Decancq, K., and Lugo, M. A. (2013), "Weights in multidimensional indices of wellbeing: An overview," Econometric Reviews, 32, 7-34.

Decoster, A. and Haan, P., (2015) "Empirical welfare analysis with preference heterogeneity," International Tax and Public Finance, 22(2), 224-251.

Dolan, P., and Kahneman, D. (2008), "Interpretations of Utility and Their Implications for the Valuation of Health," The Economic Journal, 118, 215-234.

Devoto, F., Duflo, E., Dupas, P., Pariente, W., and Pons, V. (2011). "Happiness on tap: Piped water adoption in urban Morocco (No. w16933),” National Bureau of Economic Research.

Easterlin, R. A. (1974), "Does economic growth improve the human lot? Some empirical evidence," Nations and households in economic growth, 89, 89-125.

Fleurbaey M (2008) Fairness, responsibility and welfare. Oxford University Press, Oxford

Fleurbaey, M. (2009), "Beyond GDP: The quest for a measure of social welfare," Journal of Economic Literature, 47, 1029-1075. 
Formby, J., Smith, J., Zheng, B. (2004), "Mobility measurement, transition matrices and statistical inference," Journal of Econometrics, 120, 181-205.

Heckman, J, Pinto, R. and Savelyev, P. (2013), "Understanding the Mechanisms Through Which an Influential Early Childhood Program Boosted Adult Outcomes," American Economic Review, 103, 2052-2086.

Helliwell, J. F. (2003), "How's life? Combining individual and national variables to explain subjective wellbeing," Economic Modelling, 20, 331-360.

Howes, S. (1996), "A new test for inferring dominance from sample data," Discussion Paper, STICERD, London School of Economics.

Jones, C. I. (2014), “Life and Growth,” Discussion paper, Stanford GSB and NBER.

Jones, C. I., and Klenow, P. J. (2010), "Beyond GDP? Welfare across countries and time," (No. w16352), National Bureau of Economic Research.

Kahneman, D., Krueger, A., Schkade, D., Schwarz, N. and Stone, A. (2004), "Toward National Well-being Accounts," American Economic Review, 94, 429-434.

Keefer, P. and Khemani, S. (2005), "Democracy, public expenditures, and the poor: understanding political incentives for providing public services," World Bank Research Observer, 20, 1-27.

Klemisch-Ahlert, M. (1993), "Freedom of Choice: A Comparison of Different Rankings of Opportunity Sets," Social Choice and Welfare, 10, 189-207.

Ludwig J., Duncan G. J., Gennetian, L. A., Katz, L.F., Kessler, R.C., Kling, J.R., Sanbonmatsu, L. (2013), "Long-Term Neighbourhood Effects on Low-Income Families: Evidence from Moving to Opportunity, NBER Working Paper Series, 17772.

Nehring, K. and Puppe, C. (2002), “A Theory of Diversity,” Econometrica, 70, 1155-1198.

Nussbaum, M. (2000), Women and Human Development: The Capabilities Approach (Cambridge University Press, Cambridge).

OECD (2011), Better Life Compendium, Paris, France.

ONS (2012), "Initial Findings from the Consultation on Proposed Domains and Measures of National Wellbeing," http://www.ons.gov.uk/ons/dcp171766_257206.pdf (accessed 16th January 2015)

Peichl, A. and Pestel, N. (2013), "Multidimensional Affluence: Theory and Applications to Germany and the US", Applied Economics, 45(32), 4591-4601.

Ravallion, M. (2011), “On multidimensional indices of poverty,” The Journal of Economic Inequality, 9, 235248.

Schokkaert, E. and van Ootegem L. (1989), "Sen's concept of living standard applied to the Belgian unemployed," Discussion Paper, K.U. Leuven, Belgium

Sen, A. (1985). Commodities and Capabilities, Amsterdam, North-Holland.

Sen, A. (1999). Development as a Freedom, Oxford: OUP Oxford. 
Sen, A., Williams, B., and Williams, B. A. O. (Eds.). (1982). Utilitarianism and beyond. Cambridge University Press.

Simon, J., Anand, P., Gray, A., Rugkåsa, J., Yeeles, K. and Burns, T. (2013), “Operationalising the capability approach for outcome measurement in mental health research," Social Science \& Medicine, 98, 187196.

Stiglitz, J., Sen, A. and Fitoussi J-P. (2009), Report by the Commission on the Measurement of Economic Performance and Social Progress.

Suzumura, K. and Xu, Y. (2009), "Consequentialism and Non-Consequentialism," in Handbook of Rational and Social Choice, Oxford, Oxford University Press.

UN Development Programme (UNDP), Human Development Report 2013, "The Rise of the South: Human Progress in a Diverse World," Oxford, Oxford University Press

White, M. P. and Dolan, P. (2009), "Accounting for the richness of daily activities," Psychological Science, 20, 1000-1008.

Yalonetzky, G. (2013), "Stochastic dominance with ordinal variables: Conditions and a test," Econometric Reviews, 32, 126-163. 


\section{Appendix A: Descriptive Statistics}

Table A1: "Overall how satisfied are you with your life nowadays"

\begin{tabular}{cccccccccccc}
\hline Score & 0 & 1 & 2 & 3 & 4 & 5 & 6 & 7 & 8 & 9 & 10 \\
\% of respondents (US) & 2.17 & 1.13 & 3.12 & 7.18 & 6.70 & 12.65 & 11.99 & 20.68 & 18.79 & 9.44 & 6.14 \\
& & & & & & & & & & & \\
\% of respondents (UK) & 2.90 & 2.07 & 4.74 & 7.87 & 6.81 & 12.55 & 14.21 & 23.21 & 16.87 & 5.57 & 3.20 \\
\hline
\end{tabular}

Note: $\mathrm{N}=1,059$ for US sample and 1,689 for UK sample 
Table A2: Non-cognitive skills

\begin{tabular}{|c|c|c|}
\hline Skill & Mean score US & Mean score UK \\
\hline I can strike up a conversation with most new people I meet & 6.84 & 6.45 \\
\hline I can diffuse a difficult situation & 6.73 & 6.25 \\
\hline I can provide leadership in a group & 7.01 & 6.26 \\
\hline I can take guidance from a group-leader & 7.67 & 7.15 \\
\hline I can negotiate effectively & 7.15 & 6.67 \\
\hline I can see things from other people's point of view & 7.96 & 7.58 \\
\hline I can plan for the future & 7.27 & 6.64 \\
\hline I can keep to deadlines & 7.77 & 7.30 \\
\hline I know what I like & 8.42 & 7.97 \\
\hline I know my own strengths and weaknesses & 8.21 & 7.78 \\
\hline I have a clear idea of how I want to spend the next five years & 6.98 & 6.10 \\
\hline
\end{tabular}

Note: $\mathrm{N}=1,059$ for US sample and 1,689 for UK sample

Table A3: Personality traits

\begin{tabular}{lcr}
\hline \multicolumn{2}{l}{ "Please indicate how much you agree or disagree with the following statements on a scale of 0 to 10, where 0 } \\
indicates you strongly disagree and 10 that you strongly agree. Thinking about your personality..." \\
\hline Trait & Mean score US & Mean score UK \\
\hline I see myself as extroverted, enthusiastic & 5.49 & 4.75 \\
I see myself as critical, quarrelsome & 3.97 & 4.15 \\
I see myself as dependable, self-disciplined & 7.57 & 6.91 \\
I see myself as anxious, easily upset & 4.06 & 4.54 \\
I see myself as open to new experiences, complex & 6.99 & 6.28 \\
I see myself as reserved, quiet & 5.96 & 5.79 \\
I see myself as sympathetic, warm & 7.26 & 6.95 \\
I see myself as disorganised, careless & 3.15 & 3.17 \\
I see myself as calm, emotionally stable & 6.92 & 6.08 \\
I see myself as conventional, uncreative & 3.73 & 4.22
\end{tabular}

Notes: (i) N=1,059 for US sample; (ii) For UK sample, $\mathrm{N}=1,616$ for "reserved," "sympathetic," "disorganised," "calm" and "conventional." N=1,689 for all other response items. 
Table A4: Health questions

\begin{tabular}{lcc}
\hline \hline $\begin{array}{l}\text { "For each of the following areas, please choose the statement that best } \\
\text { describes your state of health today." }\end{array}$ & $\begin{array}{c}\text { \% of } \\
\text { respondents } \\
\text { US }\end{array}$ & $\begin{array}{c}\% \text { of } \\
\text { respondents } \\
\text { UK }\end{array}$ \\
\hline Mobility & 83.1 & 84.3 \\
I have no problems in walking about & 16.1 & 15.5 \\
I have some problems in walking about & 0.9 & 0.2 \\
I am confined to bed & & \\
& & \\
Self-care & 95.5 & 92.4 \\
I have no problems with self-care & 4.0 & 7.2 \\
I have some problems washing or dressing myself & 0.6 & 0.4 \\
I am unable to wash or dress myself & & \\
& & \\
Usual activities (e.g work, study, housework, family or leisure & 81.6 & 83.8 \\
I have no problems with performing my usual activities & 16.5 & 13.7 \\
I have some problems with performing my usual activities & 1.8 & 2.6 \\
I am unable to perform my usual activities & & \\
& & \\
Pain / discomfort & 51.8 & 63.9 \\
I have no pain or discomfort & 41.8 & 30.7 \\
I have moderate pain or discomfort & 6.3 & 5.5 \\
I have extreme pain or discomfort & & \\
Anxiety / depression & & \\
I am not anxious or depressed & 54.5 & 57.3 \\
I am moderately anxious or depressed & 39.0 & 35.7 \\
I am extremely anxious or depressed & 6.5 & 7.0 \\
\hline
\end{tabular}

Notes: 1 . N=1,059 for US sample and 1,689 for UK sample; 2 . The overall index of health is calculated using widely used weights and is available as a user-written Stata command ("eq5d"). 
Table A5(a): Socio-demographics

\begin{tabular}{lcccc}
\hline \hline & \multicolumn{2}{c}{ US } & \multicolumn{2}{c}{ UK } \\
& Mean & S.D. & Mean & S.D. \\
\hline Age & 40.03 & 11.33 & 40.14 & 11.32 \\
Gender (Male=1) & 0.50 & 0.50 & 0.50 & 0.50 \\
Ethnicity (White=1) & 0.80 & 0.40 & 0.96 & 0.19 \\
Equivalised Household Income (f) & 25961.35 & 22842.02 & 22760.51 & 17627.92 \\
Have above school education & 0.752 & 0.432 & 0.57 & 0.49 \\
\hline
\end{tabular}

Notes: 1. For US sample, $\mathrm{N}=1,021$ for Equivalised Household Income; $\mathrm{N}=1,059$ for all other variables; 2. For UK sample, $\mathrm{N}=1,630$ for Equivalised Household Income; $\mathrm{N}=1,663$ for White; $\mathrm{N}=1,689$ for all other variables.

Table A5(b): Employment characteristics

\begin{tabular}{lcc}
\hline \hline Job type & Percentage US & Percentage UK \\
\hline Professional & 36.3 & \\
Employer/manager & 9.4 & \\
Non-manual & 6.0 & \\
Skilled Manual & 8.3 & \\
Semi-skilled & 7.3 & \\
Personal Services & 5.7 & \\
Unskilled & 6.0 & \\
Armed Services & 0.9 & \\
Other & 15.0 & \\
Never been employed & 5.2 & \\
\hline
\end{tabular}

Note: $\mathrm{N}=1,059$ 
Table A5(c): Geographic Regions

\begin{tabular}{lcc}
\hline \hline Region & Percentage US & Percentage UK \\
\hline Northeast & 24.93 & \\
Midwest & 24.93 & \\
South & 25.21 & \\
West & 24.93 & \\
& & \\
North East & & 1.42 \\
North West & 4.09 \\
Yorkshire and the Humber & 3.43 \\
East Midlands & 3.49 \\
West Midlands & 3.2 \\
East of England & 3.32 \\
London & 4.68 \\
South East & 6.81 \\
South West & 4.2 \\
Wales & & 31.44 \\
Scotland & 33.87 \\
Northern Ireland & 0.06 \\
\hline
\end{tabular}

Note: $\mathrm{N}=1,059$ for US sample; $\mathrm{N}=1,689$ for UK sample 
Table A5(d): Religious beliefs

\begin{tabular}{lcc}
\hline \hline Religion & Percentage US & Percentage UK \\
\hline Christian & 55.05 & 38.84 \\
Jewish & 2.83 & 0.53 \\
Muslim & 0.66 & 0.65 \\
Buddhist & 1.98 & 0.83 \\
Hindu & 0.57 & 0.65 \\
Atheist & 10.10 & 27.06 \\
Agnostic & 10.48 & 14.68 \\
Prefer not to say & 6.14 & 9.83 \\
Other & 12.19 & 6.93 \\
\hline
\end{tabular}

Note: $\mathrm{N}=1,059$ for US sample; $\mathrm{N}=1,689$ for UK sample 
SUPPLEMENTARY MATERIALS: FOR ONLINE PUBLICATION ONLY

Table S1(a) First and Second Order Dominance Test Results for Italy: Whites compared with NonWhites

\begin{tabular}{ccccccc}
\hline \hline & \multicolumn{2}{c}{ Home } & \multicolumn{2}{c}{ Work } & \multicolumn{2}{c}{ Environment } \\
\hline$k$ & $\widehat{\Delta F}(k)$ & $\widehat{\Delta H}(k)$ & $\widehat{\Delta F}(k)$ & $\widehat{\Delta H}(k)$ & $\widehat{\Delta F}(k)$ & $\widehat{\Delta H}(k)$ \\
\hline 0 & -0.185 & -0.185 & -0.2345 & -0.2345 & -0.2586 & -0.2586 \\
1 & -0.1965 & -0.3815 & -0.2147 & -0.4492 & -0.2936 & -0.5522 \\
2 & -0.108 & -0.4895 & -0.1808 & -0.63 & -0.2552 & -0.8074 \\
3 & -0.0715 & -0.561 & -0.1398 & -0.7698 & -0.0873 & -0.8947 \\
4 & -0.0586 & -0.6196 & -0.0819 & -0.8517 & -0.0533 & -0.948 \\
5 & -0.1652 & -0.7848 & 0.0777 & -0.774 & & \\
6 & -0.0035 & -0.7883 & & & & \\
7 & & & & & & \\
\hline Test & Whites & Whites & NR & Whites & Whites & Whites \\
Result & FOSD & SOSD & & SOSD & FOSD & SOSD $* *$ \\
\hline
\end{tabular}

Note: 1 . N=983 for whites \& 20 for non-whites for Home and Environment; $\mathrm{N}=708$ for whites $\& 12$ for non-whites for Work.

Table S1(b) First and Second Order Dominance Test Results for Italy: Males compared with Females

\begin{tabular}{ccccccc}
\hline \hline & \multicolumn{2}{c}{ Home } & \multicolumn{2}{c}{ Work } & \multicolumn{2}{c}{ Environment } \\
\hline$k$ & $\widehat{\Delta F}(k)$ & $\widehat{\Delta H}(k)$ & $\widehat{\Delta F}(k)$ & $\widehat{\Delta H}(k)$ & $\widehat{\Delta F}(k)$ & $\widehat{\Delta H}(k)$ \\
\hline 0 & 0.0416 & 0.0416 & 0.0282 & 0.0282 & 0.0735 & 0.0735 \\
1 & 0.0155 & 0.0571 & 0.0146 & 0.0428 & -0.0025 & 0.071 \\
2 & 0.0054 & 0.0625 & -0.0193 & 0.0235 & -0.0546 & 0.0164 \\
3 & 0.0172 & 0.0797 & 0.0043 & 0.0278 & -0.0888 & -0.0724 \\
4 & -0.0169 & 0.0628 & 0.0295 & 0.0573 & -0.0454 & -0.1178 \\
5 & -0.0092 & 0.0536 & 0.0169 & 0.0742 & & \\
6 & -0.0275 & 0.0261 & & & & \\
7 & & & & & & \\
\hline Test & NR & Females & NR & Females & NR & NR \\
Result & & SOSD & & SOSD & & \\
Nest
\end{tabular}

Note: $1 . \mathrm{N}=502$ for males \& 501 for females for Home and Environment; $\mathrm{N}=403$ for males \& 317 for females for Work. 
Table S2 Ranks of individual capabilities in Italy

\begin{tabular}{|c|c|}
\hline What people are able to do & Rank \\
\hline Practice my religious beliefs & 1 \\
\hline Get to a range of shops & 2 \\
\hline Express my political views when I wish & 3 \\
\hline Make use of banking and personal finance services & 4 \\
\hline Get to places I need to without difficulty & 5 \\
\hline Use my talents and skills at work & 6 \\
\hline Visit parks or countryside whenever I want & 7 \\
\hline Am treated where I live as an equal (and not discriminated against) & 8 \\
\hline Socialise with others in family as I would wish & 9 \\
\hline Feel valued and loved & 10 \\
\hline Keep a pet or animal at home with ease if I so wish & 11 \\
\hline Be treated by a doctor or nurse & 12 \\
\hline Get my rubbish cleared away & 13 \\
\hline Socialise at work & 14 \\
\hline Enjoy the kinds of personal relationships that I want & 15 \\
\hline Achieve a good work life balance & 16 \\
\hline Be treated as an equal (and not discriminated against) by people at work & 17 \\
\hline Find a home suitable for my needs & 18 \\
\hline Walk in my local neighbourhood safely at night & 19 \\
\hline Share domestic tasks with the household fairly & 20 \\
\hline Get help from the police & 21 \\
\hline Get help from a solicitor & 22 \\
\hline Make ends meet & 23 \\
\hline Get trades people or the landlord to help fix problems in the house & 24 \\
\hline Work under a good manager at the moment & 25 \\
\hline Take part in local social events & 26 \\
\hline Find work when I need to & 27 \\
\hline Work in an environment that has little pollution & 28 \\
\hline Be promoted or recognised at work & 29 \\
\hline
\end{tabular}

Notes: 1 . Rank 1 indicates the highest average score; rank 29 indicates the lowest;

2. $\mathrm{N}=720$ for Work related responses; $\mathrm{N}=1,003$ for all other responses. 
Table S3 Non-cognitive skills, income and life satisfaction in Italy

\begin{tabular}{|c|c|c|c|c|c|c|}
\hline & \multicolumn{2}{|c|}{ Log Income } & \multicolumn{4}{|c|}{ Life Satisfaction } \\
\hline & OLS & OLS & O. Probit & O. Probit & O. Probit & 2SLS \\
\hline \multicolumn{7}{|l|}{ Non-cognitive skills } \\
\hline Can take Guidance & $\begin{array}{l}-0.006 \\
(0.023)\end{array}$ & $\begin{array}{l}0.007 \\
(0.022)\end{array}$ & $\begin{array}{l}0.016 \\
(0.064)\end{array}$ & $\begin{array}{l}0.014 \\
(0.060)\end{array}$ & & \\
\hline See other views & $\begin{array}{l}-0.073 * * * \\
(0.028)\end{array}$ & $\begin{array}{l}-0.058 * * \\
(0.027)\end{array}$ & $\begin{array}{l}0.023 \\
(0.051)\end{array}$ & $\begin{array}{l}0.033 \\
(0.055)\end{array}$ & & \\
\hline Can plan future & $\begin{array}{l}0.034 \\
(0.025)\end{array}$ & $\begin{array}{l}0.027 \\
(0.025)\end{array}$ & $\begin{array}{l}0.141 * * \\
(0.059)\end{array}$ & $\begin{array}{l}0.108 * \\
(0.060)\end{array}$ & & \\
\hline Know what I like & $\begin{array}{l}0.000 \\
(0.031)\end{array}$ & $\begin{array}{l}0.024 \\
(0.027)\end{array}$ & $\begin{array}{l}0.045 \\
(0.053)\end{array}$ & $\begin{array}{l}0.051 \\
(0.057)\end{array}$ & & \\
\hline Know strengths \& weaknesses & $\begin{array}{l}-0.007 \\
(0.031)\end{array}$ & $\begin{array}{l}-0.027 \\
(0.033)\end{array}$ & $\begin{array}{l}-0.003 \\
(0.057)\end{array}$ & $\begin{array}{l}0.013 \\
(0.063)\end{array}$ & & \\
\hline Have 5 year plan & $\begin{array}{l}0.019 \\
(0.020)\end{array}$ & $\begin{array}{l}0.031 * \\
(0.019)\end{array}$ & $\begin{array}{l}0.117 * * * \\
(0.045)\end{array}$ & $\begin{array}{l}0.091 * * \\
(0.045)\end{array}$ & & \\
\hline Can provide leadership & $\begin{array}{l}0.023 \\
(0.024)\end{array}$ & $\begin{array}{l}0.011 \\
(0.024)\end{array}$ & & & & \\
\hline Good at sports & $\begin{array}{l}0.006 \\
(0.016)\end{array}$ & $\begin{array}{l}0.013 \\
(0.017)\end{array}$ & $\begin{array}{l}0.104 * * * \\
(0.030)\end{array}$ & $\begin{array}{l}0.074 * * \\
(0.033)\end{array}$ & & \\
\hline Non-cognitive skills index & & & & & $\begin{array}{l}0.172 * * * \\
(0.043)\end{array}$ & $\begin{array}{l}0.243 \\
(0.471)\end{array}$ \\
\hline \multicolumn{7}{|l|}{ Controls } \\
\hline Income & & & & $\begin{array}{l}0.392 * * * \\
(0.113)\end{array}$ & $\begin{array}{l}0.459 * * * \\
(0.119)\end{array}$ & $\begin{array}{l}0.726^{* * * *} \\
(0.193)\end{array}$ \\
\hline Unemployed & & $\begin{array}{l}-0.344 * * * \\
(0.108)\end{array}$ & & $\begin{array}{l}-0.310 \\
(0.204)\end{array}$ & $\begin{array}{l}-0.323 \\
(0.199)\end{array}$ & $\begin{array}{l}-0.509 \\
(0.343)\end{array}$ \\
\hline Married or partnered & & $\begin{array}{l}-0.005 \\
(0.092)\end{array}$ & & $\begin{array}{l}0.015 \\
(0.165)\end{array}$ & $\begin{array}{l}0.152 \\
(0.159)\end{array}$ & $\begin{array}{l}0.338 \\
(0.299)\end{array}$ \\
\hline Health & & $\begin{array}{l}-0.010 \\
(0.235)\end{array}$ & & $\begin{array}{l}0.954 * * \\
(0.389)\end{array}$ & $\begin{array}{l}1.177 * * * \\
(0.388)\end{array}$ & $\begin{array}{l}2.066^{* * * *} \\
(0.732)\end{array}$ \\
\hline Education & & Yes & & Yes & Yes & Yes \\
\hline Sex, Ethnicity, Age, Age $^{2} \&$ & & Yes & & Yes & Yes & Yes \\
\hline $\begin{array}{l}\text { Personality } \\
\mathrm{N}\end{array}$ & 261 & 261 & 263 & 261 & 261 & 261 \\
\hline AIC & 486.1847 & 463.5244 & 1020.245 & 1008.113 & 1016.045 & \\
\hline Adj R-Sq (OLS)/Pseudo R-Sq (O. Probit) & 0.0078 & 0.1318 & 0.0859 & 0.1179 & 0.0994 & \\
\hline
\end{tabular}

Note: The instrumental variable in the 2SLS regression is the predicted value from a regression of the noncognitive skills index on participation yesterday in a number of daily activities - cooking, drinking, exercising and spending time with children. The F-stat in the first-stage regression is 4.4 , indicating a rather weak instrument. 
Table S4(a): Activity Models for Italy

Caring

Cooking

DIY

Drinking

Volunteering

Human development indicators

Log Income

Health

Education

Non-cognitive skills index

$\begin{array}{ccccc}-0.357^{*} & 0.195 & -0.182 & 0.383^{* *} & -0.407^{*} \\ (0.191) & (0.154) & (0.164) & (0.173) & (0.217) \\ -0.159 & -0.120 & 0.092 & -0.379 & 0.064 \\ (0.565) & (0.524) & (0.520) & (0.533) & (0.633) \\ -0.137 & -0.228 & -0.032 & 0.194 & -0.145 \\ (0.229) & (0.186) & (0.195) & (0.188) & (0.276) \\ -0.002 & 0.014^{*} & -0.002 & 0.005 & 0.011 \\ (0.009) & (0.008) & (0.008) & (0.008) & (0.011)\end{array}$

Personal Characteristics and Social Resource Indicators

Unemployed

Married or Partnered

$(0.377)$

0.194

(0.244)

Male

$-0.239$

$(0.202)$

0.421

$0.248-0.002$

0.248

(0.214)

$-1.135^{* * * *}$

$-0.002$

(0.192)

$(0.219)$

$0.187)$

$(0.557)$

(0.539)

$-0.033$

(0.354)

0.126

(0.205)

0.240

(0.186)

0.215
$(0.441)$

Controls for age

Yes

Yes

Yes

Yes

Yes

N

$252 \quad 261$

226.3805
0.0957

306.2124
0.2239

261
303.7209

303.7209
0.0795

299.0485

252
137.4497
0.2027

Pseudo R-Sq.

NOTES: 1. Controls included for personality; 2. Income variable is adjusted for household composition using the Modified OECD equivalence scale; 3 . Education is a binary variable indicating an above high school education; 4. Non-cognitive skills index is obtained by summing across all eleven non-cognitive skills listed in Table A2 and B4; 5. Controls for age include age and age squared. 
Table S4(b): Leisure Activity Models for Italy

\begin{tabular}{|c|c|c|c|c|}
\hline & $\begin{array}{l}\text { Logged Out of Home } \\
\text { Leisure (OLS) }\end{array}$ & $\begin{array}{l}\text { Out of Home Leisure } \\
\text { (Ordered Probit) }\end{array}$ & $\begin{array}{c}\text { Logged Indoor Leisure } \\
(\mathrm{OLS})\end{array}$ & $\begin{array}{c}\text { Indoor Leisure (Ordered } \\
\text { Probit) }\end{array}$ \\
\hline \multicolumn{5}{|l|}{ Human development indicators } \\
\hline Log Income & $\begin{array}{l}0.041 \\
(0.073)\end{array}$ & $\begin{array}{c}0.073 \\
(0.145)\end{array}$ & $\begin{array}{l}0.158 * * * \\
(0.058)\end{array}$ & $\begin{array}{l}0.318 * * \\
(0.130)\end{array}$ \\
\hline Health & $\begin{array}{c}0.204 \\
(0.211)\end{array}$ & $\begin{array}{c}0.501 \\
(0.458)\end{array}$ & $\begin{array}{l}-0.116 \\
(0.180)\end{array}$ & $\begin{array}{l}-0.143 \\
(0.370)\end{array}$ \\
\hline Education & $\begin{array}{c}0.021 \\
(0.087)\end{array}$ & $\begin{array}{c}0.039 \\
(0.163)\end{array}$ & $\begin{array}{l}-0.043 \\
(0.069)\end{array}$ & $\begin{array}{l}-0.022 \\
(0.152)\end{array}$ \\
\hline Non-cognitive skills index & $\begin{array}{l}0.008 * * \\
(0.003)\end{array}$ & $\begin{array}{c}0.015 * * \\
(0.006)\end{array}$ & $\begin{array}{c}0.007 * * * \\
(0.003)\end{array}$ & $\begin{array}{c}0.015 * * * \\
(0.006)\end{array}$ \\
\hline \multicolumn{5}{|c|}{ Personal Characteristics and Social Resource Indicators } \\
\hline Unemployed & $\begin{array}{l}-0.003 \\
(0.143)\end{array}$ & $\begin{array}{l}-0.033 \\
(0.273)\end{array}$ & $\begin{array}{c}0.001 \\
(0.107)\end{array}$ & $\begin{array}{l}-0.039 \\
(0.218)\end{array}$ \\
\hline $\begin{array}{l}\text { Married } \\
\text { or Partnered }\end{array}$ & $\begin{array}{c}0.004 \\
(0.089)\end{array}$ & $\begin{array}{c}0.006 \\
(0.165)\end{array}$ & $\begin{array}{l}-0.017 \\
(0.074)\end{array}$ & $\begin{array}{c}0.012 \\
(0.158)\end{array}$ \\
\hline Male & $\begin{array}{l}0.186 * * \\
(0.078)\end{array}$ & $\begin{array}{l}0.365 * * \\
(0.150)\end{array}$ & $\begin{array}{c}-0.127 * * \\
(0.063)\end{array}$ & $\begin{array}{l}-0.270^{*} \\
(0.138)\end{array}$ \\
\hline White & $\begin{array}{c}0.206 \\
(0.181)\end{array}$ & $\begin{array}{c}0.487 \\
(0.441)\end{array}$ & $\begin{array}{c}0.302 \\
(0.194)\end{array}$ & $\begin{array}{c}0.639 \\
(0.420)\end{array}$ \\
\hline Controls for age & Yes & Yes & Yes & Yes \\
\hline $\begin{array}{l}\mathrm{N} \\
\text { AIC } \\
\text { R-Sq / Pseudo R-Sq }\end{array}$ & $\begin{array}{c}261 \\
479.4982 \\
0.0950\end{array}$ & $\begin{array}{c}261 \\
760.9864 \\
0.0368\end{array}$ & $\begin{array}{c}261 \\
383.1444 \\
0.1709\end{array}$ & $\begin{array}{c}261 \\
868.3368 \\
0.0498\end{array}$ \\
\hline
\end{tabular}

NOTES: 1. Out of Home Leisure index is obtained by summing the binary indicators for activities related to going out, i.e. exercising; visiting park or countryside; visiting cinema, concert, gallery or museum; other outdoor activities; and socialising; Indoor Leisure index is obtained by summing the binary indicators for activities related to indoor activities, i.e. intimate relations; listening to music; playing music; reading; and watching television; 3. Controls included for personality; 4. Income variable is adjusted for household composition using the Modified OECD equivalence scale; 5. Education is a binary variable indicating an above high school education; 6 Non-cognitive skills index is obtained by summing across all eleven non-cognitive skills listed in Tables A4 and B4; 7. Controls for age include age and age squared. 